\title{
Materials Selection for Process Equipment in the Hanford Waste Vitrification Plant
}
M. R. Elmore
G. A. Jensen

July 1991

Prepared for the U.S. Department of Energy under Contract DE-AC06-76RLO 1830

Pacific Northwest Laboratory Operated for the U.S. Department of Energy by Battelle Memorial Institute 


\title{
DISCLAIMER
}

This report was prepared as an account of work sponsored by an agency of the United States Government. Neither the United States Government nor any agency thereof, nor Battelle Memorial Institute, nor any of their employees, makes any warranty, expressed or implied, or assumes any legal liability or responsibility for the accuracy, completeness, or usefulness of any information, apparatus, product, or process disclosed, or represents that its use would not infringe privately owned rights. Reference herein to any specific commercial product, process, or service by trade name, trademark, manu\{́acłurer, or otherwise does not necessarily constitute or imply its endorsement, recommendation, or favoring by the United States Government or any agency thereof, or Battelie Memorial Instiłute. The views and opinions of authors expressed herein do not necessarily state or reflect those of the United States Government or any agency thereof.

\author{
PACIFIC NORTHWEST LABORATORY \\ operated by \\ BATTELLE MEMORIAL INSTITUTE \\ for the \\ UNITED STATES DEPARTMENT OF ENERGY \\ under Contract DE-ACO6-76RLO 1830
}

Printed in the United States of America

Available to DOE and DOE contractors from the

Office of Scientific and Technical Information, P.O. Box 62, Oak Ridge, TN 37831;

prices available from (615) 576-8401. FTS 626-8401.

Available to the public from the National Technical Information Service, U.S. Department of Commerce, 5285 Port Royal Rd., Springfield, VA 22161. 
PNL -7729

UC -721

MATERIALS SELECTION FOR PROCESS EQUIPMENT IN THE HANFORD WASTE VITRIFICATION PLANT

M. R. Elmore

G. A. Jensen

JuTy 1991

Prepared for

the U.S. Department of Energy

under Contract DE-AC06-76RLO 1830

Pacific Northwest Laboratory

Richland, Washington 99352 


\section{SUMMARY}

The Hanford Waste Vitrification Plant (HWVP) is being designed to vitrify defense liquid high-level wastes and transuranic wastes stored at Hanford. The HWVP Functional Design Criteria (FDC) requires that materials used for fabrication of remote process equipment and piping in the facility be compatible with the expected waste stream compositions and process conditions. To satisfy FDC requirements, corrosion-resistant materials have been evaluated under simulated HWVP-specific conditions and recommendations have been made for HWVP applications. The materials recommendations provide to the project architect/engineer the best available corrosion rate information for the materials under the expected HWVP process conditions.

Existing data and sound engineering judgement must be used and a solid technical basis must be developed to define an approach to selecting suitable construction materials for the HWVP. This report contains the strategy, approach, criteria, and technical basis developed for selecting materials of construction. Based on materials testing specific to HWVP and on related outside testing, this report recommends materials for constructing specific process equipment and identifies future testing needs to complete verification of the performance of the selected materials.

Laboratory-scale and limited larger scale corrosion testing has been performed in selecting materials for the HWVP, the Defense Waste Processing Facility (DWPF), and the West Valley Demonstration Project (WVDP). Open literature and other available reports covering HWVP, DWPF and WVDP testing have been reviewed. In addition, available information provided at DWPF-HWVP information exchanges and meetings, has been reviewed. Based on the available data and information, Hastelloy $\mathrm{C}-22$ is the recommended construction material for embeds carrying process fluids and for most remote process vessels and their associated components. The recommendation of Hastelloy $\mathrm{C}-22$ for much of the process equipment and piping is based on its superior performance over a wide range of $\mathrm{pH}$, temperature, halide and nitrate concentrations, and other environmental conditions (at. no identified cost penaity compared to Hastelloy C-276). Exceptions include the waste hold tank (WHT), slurry mix evaporator condensate tank (SMECT), and the waste adjustment tank (WAT), where 316-L 
stainless steel is recommended, providing that proper temperature and $\mathrm{pH}$ control are maintained for these vessels. If any of the latter vessels are to be located so that they become nonreplaceable, Hastelloy $\mathrm{C}-22$ should be considered for them as well. Additional exceptions, such as melter construction materials, are also identified, where Monofrax K-3 is recomended for the refractory material and Inconel-690 for high-temperature metallic components.

Although preliminary design for the HWV was expected to be completed by October 1990, certain areas of the process are sti11 undergoing development. An example is the process waste handling system, where transuranic-bearing (TRU) waste streams will be processed in some manner to recycle the TRU portion back into the vitrification process. For some processing options still being considered for TRU recycle, selected materials are compatible, but only under appropriate processing conditions such as proper $\mathrm{pH}$ control. In laboratory tests simulating some of these options, the performance of Hastelloy $\mathrm{C}-22$ has been superior to that of the other alloys considered. Additional consid. erations are presented regarding materials performance (e.g., wear from abrasive slurries, electrically induced galvanic corrosion, etc.), and approaches to satisfying those by monitoring materials performance, particularly during planned testing of large-scale equipment, are provided. 


\section{ACKNOWLEDGMENTS}

This work was performed under sponsorship of the U.S. Department of Energy.

The authors gratefully acknowledge the cooperation of staff members associated with the Defense Waste Processing Facility at the Savannah River Site and staff members at the West Valley Demonstration Project. The authors also express their appreciation to Judith Powe11, who edited this report, and to D. E. Larson who provided programmatic guidance and document review. 


\section{CONTENTS}

SUMMARY

ACKNOWLEDGMENTS . . . . . . . . . . . . . . . . . . $\mathrm{v}$

ACRONYMS .......................... . . . .

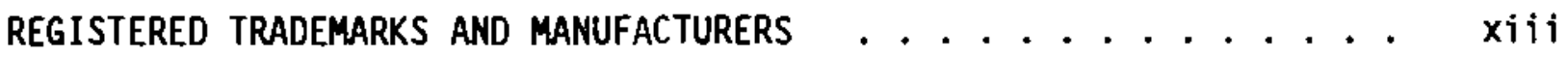

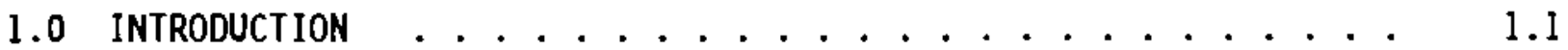

2.0 CONCLUSIONS AND RECOMMENDATIONS . . . . . . . . . . . . . 2.1

3.0 APPROACH AND BASIS FOR MATERIALS SELECTION CRITERIA . . . . . . 3.1

3.1 APPROACH DEVELOPED FOR THIS EVALUATION $\ldots . . \cdots$

3.2 BASIS FOR DEVELOPING MATERIALS SELECTION CRITERIA . . . 3.2

3.2.I Review of the FDC, TDP, and Design Codes,
and Supporting Information ............. 3.3

3.2.2 Technical Rationale for Developing HWVP
Materials Selection Criteria . . . . . 3.6 3.6

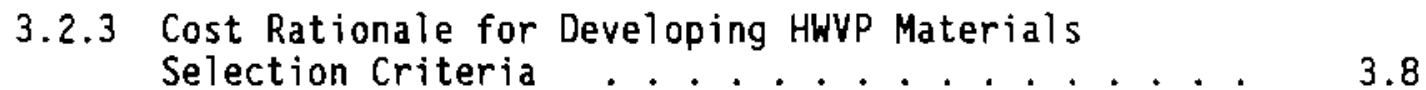

3.2.4 Risk as a Rationale for Developing HWVP
Materials Selection Criteria . . . . . . . . 3.10

4.0 MATERIALS SELECTION STRATEGY . . . . . . . . . . . . . . . . 4.1

4.1 FUNCTIONAL DESIGN CRITERIA AND MATERIALS SELECTION

CRITERIA ..................... 4.1

4.2 COMPONENTS AND EQUIPMENT FOR PROCESS AREAS . . . . . . . . 4.4

4.2.1 Process Equipment Listing . . . . . . . . . . . 4.4

4.2.2 Process Requirenents . . . . . . . . . . . . . . 4.5

4.3 STRATEgY FOR MATERIALS TESTING AND EVALUATION . . . . . . 4.9

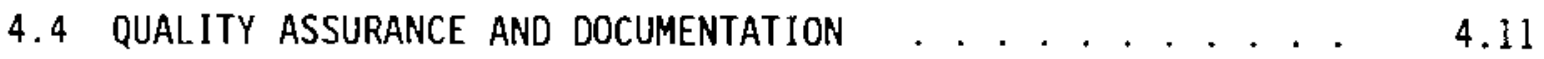


5.0 MATERIAlS TeSting ................. 5.1

5.1 LABORATORY TESTING . . . . . . . . . . 5.1

5.1.1 Laboratory Testing for DWPF . . . . . . . . 5.1

5.1.2 Laboratory Testing for WVDP . . . . . . . . 5.4

5.1 .3 Laboratory Testing for HWVP . . . . . . . 5.6

5.2 LARGER SCALE TESTING . . . . . . . . . . 5.10

5.2.1 Process-Scale Testing for DWPF . . . . . . 5.11

5.2.2 Process-ScaTe Testing for HWVP . . . . . . . . 5.13

5.3 MATERIALS TEST AND SELECTION SUMMARY . . . . . . . . 5.14

6.0 MATERIALS SELECTION ................. 6.1

6.1 SLURRY TRANSPORT PIPING EMBEDDED IN CONCRETE . . . . . . 6.1

6.2 SLURRY RECEIPT AND LAG STDRAGE . . . . . . . . . . 6.3

6.3 SLURRY PROCESSING . . . . . . . . . . . . . . 6.4

6.4 MELTER . . . . . . . . . . . . . . . . . 6.5

6.5 MELTER OFF-GAS SYSTEM . . . . . . . . . . 6.6

6.6 CONDENSED VAPOR RECOVERY AND WASTE HANDLING $\ldots \ldots . . .6 .6$

6.7 OTHER SYSTEMS . . . . . . . . . . . . . . . 6.7

7.0 ADDITIONAL MATERIALS CONSIDERATIONS . . . . . . . . . 7.1

8.0 REFERENCES ..................... 8.1

APPENDIX A - DETAILS OF HWVP MATERIALS TESTING . . . . . . . . A A.I

$\begin{aligned} \text { APPENDIX B - } & \text { MATERIALS SELECTION GUIDES FOR SELECTED HWV } \\ & \text { REMOTE PROCESS VESSELS AND EQUIPMENT . . . . . . . . B. }\end{aligned}$ 


\section{FIGURES}

4.1 Basic Flow Diagram for HWVP Process . . . . . . . . . . . 4.6

4.2 Basic Arrangement of HWV Cells . . . . . . . . . . . 4.7

5.1 Corrosion Rates Versus Halide Concentration for Construction Materials Considered for DWPF, WVDP, and HWVP . . . . . 5.16

5.2 Corrosion Rates Versus Chioride Concentration for Construction Materials Considered for DWPF, WVDP, and HWVP . . . . . . 5.16

5.3 Corrosion Rates Versus Fluoride Concentration for Construction Materials Considered for DWPF, WVDP, and HWVP . . . . . 5.17

5.4 Corrosion Rates Versus Nitrate Concentration for Construction Materials Considered for DWPF, WVDP, and HWVP . . . . . . . 5.17

5.5 Corrosion Rates Versus Mercury Concentration for Construction Materials Considered for DWPF, WVDP, and HWVP. . . . . . 


\section{IABLES}

3.1 HWVP Functional Design Criteria Affecting

Materials Selection ................... 3.4

3.2 Items To Include in Evaluating Costs of Process

Equipment Materials ............... 3.9

3.3 Cost Comparison for Slurry Receipt and Adjustment

Tank Using Carpenter $20 \mathrm{Cb}-3$ or Hastelloy C-276 for

Construction ................. 3.11

4.1 HWVP Chemical Process Equipment Requiring Materials

Selection ................... 4.5

4.2 HWVP Reference Feed Compositional Range . . . . . . . . . . 4.8

5.1 Chemical Composition of Alloys Tested at SRL . . . . . . 5.2

5.2 Conditions Chosen for SRL Preliminary Scouting and Verification Testing .............. 5.3

5.3 Approximate Compositions of Solutions for WVDP Tests . . . 5.5

5.4 Results of WVDP Corrosion Evaluations Shared with PNL . . . . 5.6

5.5 Compositions of FY 1989 HWVP Corrosion Test Solutions . . . . 5.9

6.1 Materials Recommendations for Major Components of HWVP
Chemical Process Equipment . . . . . . . . 6.2 


\section{ACRONYMS}

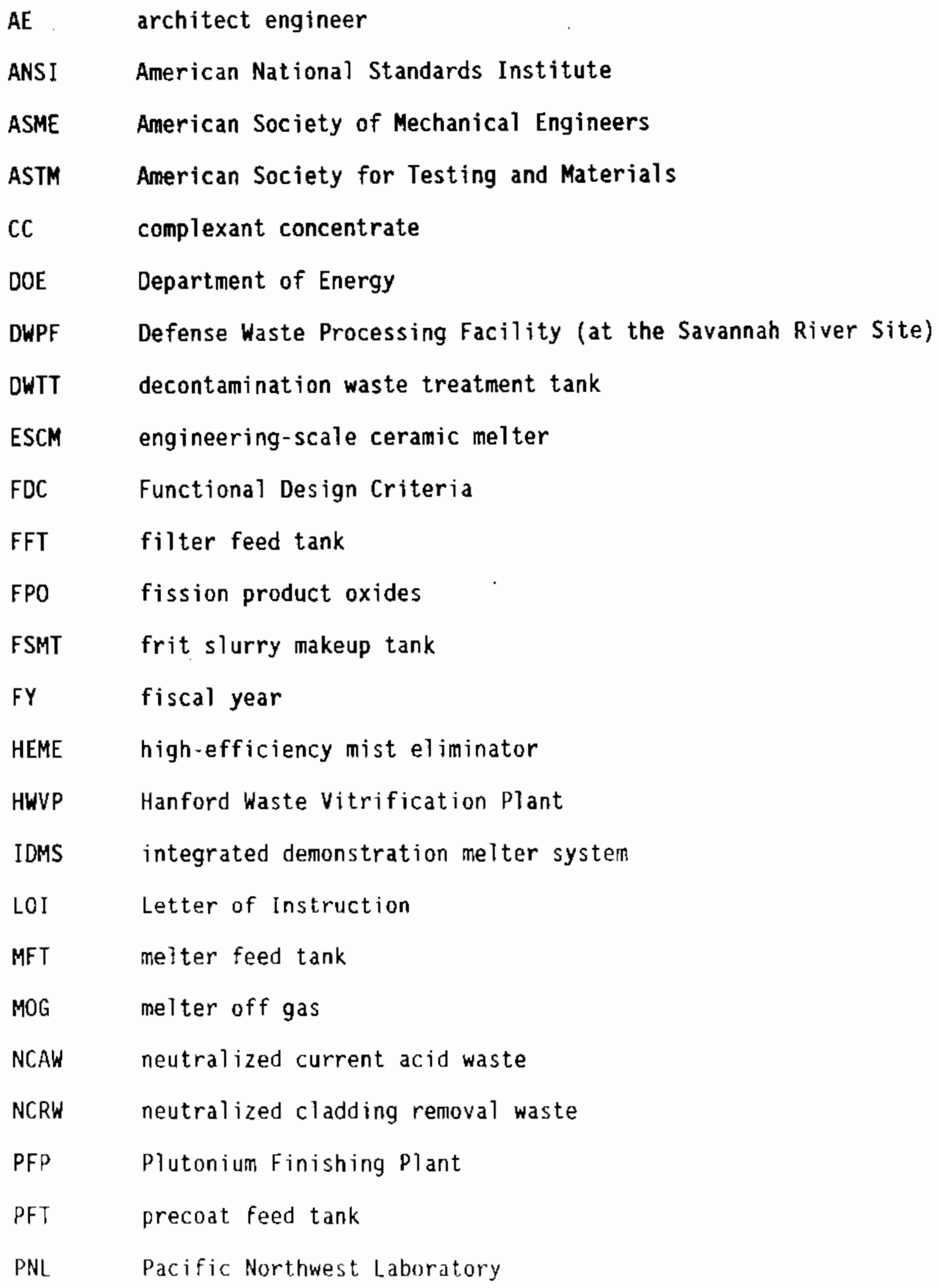




\begin{tabular}{|c|c|}
\hline PRMC & (HWVP) Project Records Management Center \\
\hline PSCM & pilot-scale ceramic melter \\
\hline PUREX & Plutonium/URanium EXtraction Facility \\
\hline PVV & process vessel vent \\
\hline RLST & receipt and lag storage tank \\
\hline RWCT & recycle waste collection tank \\
\hline SBS & submerged bed scrubber \\
\hline SEM & scanning electron microscopy \\
\hline SGM & scale glass melter \\
\hline SME & slurry mix evaporator \\
\hline SMECT & slurry mix evaporator condensate tank \\
\hline SRAT & slurry receipt and adjustment tank \\
\hline SRL & Savannah River Laboratory \\
\hline SRL-TNX & SRL Engineering Test Facility \\
\hline SRP & Savannah River Plant \\
\hline SRS & Savannah River Site \\
\hline SST & submerged-bed-scrubber surge tank \\
\hline TDP & Technical Data Package \\
\hline TOC & total organic carbon \\
\hline TRU & transuranic \\
\hline WAT & waste adjustment tank \\
\hline WHC & Westinghouse Hanford Company \\
\hline WHT & waste hold tank \\
\hline WVDP & West Valley Demonstration Project \\
\hline
\end{tabular}




\section{REGISTERED TRADEMARKS AND MANUFACTURERS}

$\begin{array}{ll}\text { ALLCORR } & \text { Teledyne Allvac } \\ \text { Carpenter 20 Cb-3 } & \text { Carpenter Technology Corporation } \\ \text { Hastelloy } & \text { Haynes International } \\ \text { HRI3 } & \text { Sumitomo Metal Industries, Limited } \\ \text { Inconel } & \text { Inco Alloys International } \\ \text { Monofrax } & \text { Carborundum Corporation } \\ \text { Sanicro 28 } & \text { Sandvik Special Metals Corporation } \\ \text { Stellite } & \text { Stoody Co., Division of Stoody } \\ & \text { Deloro Steilite, Inc. }\end{array}$


Y
S 


\subsection{INTRODUCTION}

The Hanford Waste Vitrification Plant (HWVP) is being designed to process various chemically diverse high-level and transuranic wastes stored at Hanford. Among these are neutralized current acid waste (NCAW), complexant concentrate (CC), Plutonium Finishing Plant (PFP) waste, neutralized cladding removal waste (NCRW), and perhaps single-shell tank wastes. Suitable materials for remote equipment and piping must be selected for the safe and efficient operation of the HWVP. Compliance with the HWVP Functional Design Criteria (FDC) requires that materials used for fabrication of remote process equipment and piping be compatible with expected waste stream compositions and process conditions throughout the life of the HWVP. The standard guides for selecting materials for process equipment are not entirely suitable for HWVP applications because of unique and complex physical and chemical conditions anticipated in the process system. To satisfy FDC requirements, the HWVP process system is being rigorously evaluated and materials have been tested to select and/or verify performance of candidate alloys for HWV-specific conditions.

The purpose of the materials evaluation is to provide design guidance to

the architect/engineer ( $A E)$ by identifying suitable construction materials for remote piping and process equipment in the HWVP and by providing the best available information on corrosion (and localized corrosion) rates for the identified materials. The final selection of materials of construction will be made by the architect/engineer during completion of the detailed design. Glass frit and other suspended solids can increase the rate of metal loss. Velocity of the fluid and abrasiveness of the solids can act synergistically with chemical attack, significantly accelerating metal loss from vessels, piping, pumps, and other HWVP components. The effect of erosion and velocity on corrosion must also be addressed as a part of the process to evaluate materials. Sufficient information is availabie through the open literature to select suitable materials for the nonradioactive equipment and piping to handle dry frit, frit slurry, and other nonradioactive process chemicals. Areas where additional guidance must be developed and provided to the $A E$ are the 
equipment and components associated with feed slurry receipt, slurry processing, melter, melter off-gas treatment, and radioactive waste handling.

The principal objectives of this study were to:

- recommend reference materials of construction for remote process equipment and piping for use in design where suitable information exists

- prepare and issue a report covering selection of materials for HWVP embedded piping and slurry receipt, slurry processing, and process waste handling vessels, melter components, and melter off-gas treatment system.

To ensure that these objectives have been met, this report includes a strategy and approach, the materials selection criteria and technical basis developed for selecting materials of construction. For completeness, this report also includes information from earlier HWVP materials evaluation efforts as well as additional information developed for the Defense Waste Processing Facility (DWPF) and the West Valley Demonstration Project (WVDP) that has not been included in previous HWVP documents.

The conclusions and recommendations from this study are found in the forlowing section (Section 2.0). Details concerning the approach, basis, and strategy for materials selection for the HWVP are reported in Sections 3.0 and 4.0. A summary of materials testing for HWVP, DWPF, and WVOP is presented in Section 5.0. Materials selection recommendations for HWVP based on the available information are identified in Section 6.0. Section 7.0 outlines some additional monitoring of materials performance that the authors believe is necessary to ensure adequate performance for the recommended HWVP reference materials of construction. 


\subsection{CONCLUSIONS AND RECOMMENDATIONS}

The following conclusions and recomendations were developed as a result of this effort to select suitable materials of construction for remote process equipment and piping in the HWVP. These recomedations are based on available information and the preliminary design status of HWVP. In the detailed design process, additional considerations or engineering trade-off studies could affect the final choice and specification of materials for HWVP construction. More specific materials recommendations and supporting information are presented in later sections of this report.

Conclusion - Based on testing and other available information, Hastelloy C-22 offers the best corrosion resistance of those materials tested for feed preparation and process waste handling systems under simulated HWVP process stream compositions and conditions for NCAW.

Recormendation - Hastelloy $\mathrm{C}-22$ is recommended to fabricate major components of the remote process equipnent and piping in contact with process slurries and most process waste solutions.

Conclusion - Although Hastelloy C-22 exhibits the best corrosion resistance to simulated process solutions and conditions of the materials tested, data are somewhat limited for $i$ ts performance at high halide concentrations and low $\mathrm{pH}$ simulating process recycle waste conditions.

Recommendation - The performance of Hastelloy C-22 under certain process recycle waste conditions, such as very high halide concentrations $\left(\mathrm{F}^{-}+\mathrm{Cl}^{-}>10,000 \mathrm{ppm}\right)$ and $10 \mathrm{w} \mathrm{pH}(\mathrm{pH}<2)$, is uncertain. The process recycle waste solutions should be neutralized to a $\mathrm{pH}$ of 3 or higher to avoid potentially unacceptable conditions to the construction materials.

Conclusion - For certain less aggressive chemical environments in the plant, such as for the slurry mix evaporator condensate tank (SMECT) vessel and components, 304-L and 316-L stainless steels are suitable materials for fabricating certain process equipment. 
Recomendation - 304-L stainiess steel is recomended as the material for equipment and piping in contact with process water and chemical addition lines (except for formic acid-bearing solutions) as well as some "nonwetted" components.

Recommendation - 316-L stainless steel is recommended for equipment and piping in contact with formic acid-bearing streams and for neutralized process streams entering and leaving the facility.

Conclusion - The materials identified for melter components (Monofrax K-3 ceramic for glass-contacting ceramic components and Inconel-690 for glasscontacting and high-temperature metallic components, including the off-gas 1 ine to the submerged bed scrubber [SBS]), are adequate within the operating limitations identified in previous evaluations.

Recommendation - Because of the anticipated shorter life of melter components such as other thermowells and dip tubes, an ongoing effort to identify and evaluate potentially longer lived materials or coatings for these is recommended as an objective for future melter testing.

Conclusion - Available information on materials performance for Hastelloy C-22 components exposed to abrasive slurry conditions (e.g., frit slurries) is minimal, and should be supplemented with currently planned testing. However, Hastelloy $\mathrm{C}-22$ is expected to perform similarly to Hastelloy C-276 for abrasive slurry service.

Recommendation - Hastelloy C-22, used where abrasive slurries impinge on heating/cooling coils, agitator blades, etc., should be considered in planned testing with full-scale equipment. From these evaluations, detailed recommendations for design and operation should be developed.

Conclusion - Experience with fabrication of corrosive-service equipment from special corrosion-resistant materials (especially Hastelloy C-22 and Stellite) is not widely available. All important aspects of the specification and fabrication processes need to be identified and carefully adhered to in order for the equipment to perform as expected. 
Recommendation - A team of qualified project staff should be formed to review equipment designs to identify acceptable fabrication methods using these types of materials.

Recommendation - The HWVP project should develop a reference "catalog" of approved fabrication and construction methods to be referenced concerning drawings and other design media.

Conclusion - HWV materials testing has specifically addressed the processing of currently anticipated HWVP feeds and the resultant process waste solutions. The HWVP is being designed to process wastes with different chemical compositions that may impact materials performance in the process equipment.

Recommendation - As other wastes (e.g., complexant concentrate, Plutonium Finishing Plant, neutralized cladding removal waste, etc.) are characterized and processing conditions are established for them, consideration must be given the evaluation of materials performance for the process equipment where feed compositions may fall outside the current HWV feed specifications. 


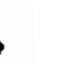




\subsection{APPROACH AND BASIS FOR MATERIALS SELECTION CRITERIA}

Existing data and sound engineering judgement have been used to properly define a strategy and approach for HWVP materials selection. The following subsections describe the approach used to select materials and develop materials selection criteria for the project.

\subsection{APPROACH DEVELOPED FOR THIS EVALUATION}

The following bulleted items outline the methodology used to establish the technical basis for selecting construction materials:

- Identify project-related requirements for establishing specific materials selection criteria.

Baseline project documents, such as the FDC and Technical Data Package (TDP), establish project requirements that influence the choice for materials selection criteria.

- Establish selection criteria with justifiable technical basis for each criterion.

Criteria established for materials selections must fulfill project requirements and must be defined as unambiguous standards for selecting construction materials.

- Identify specific equipment and piping items for which the project must provide materials selection input to the $A E$ for the design.

For certain equipment items in the HWVP, the risk of corrosion failure will have major impacts on production, operation, and maintenance. Fabrication materials for high-risk equipment, especially those exposed to corrosive and erosive conditions on which there is now little or no supporting information, must be identified for process equipment.

- Review available testing results and performance data and determine their relevance and suitability to support decisions on HWV materials selection.

Suitable data exist in the open literature, from the DWPF and the WVDP, and from other sources to support certain materials selections where expected service conditions and risk are known and well documented. Recommendations for those materials can be adequately justified with no additional evaluation. Where information on the performance of materials is limited, insufficient, or unavailable, additional testing may be required to adequately support a decision. 
- Recommend the corrosion allowances to be utilized for equipment design.

In addition to the materials selections, to provide their corrosion (and erosion) rates under specific conditions will give a basis for corrosion allowances for the equipment and piping.

By establishing the proper selection criteria and carefully reviewing available information on materials performance, the remaining objectives of the materials evaluation effort were met:

- Select materials where sufficient supporting information, test results, or other bases for sound engineering judgement exist.

Materials selections with supporting information have been compiled for appropriate plant equipment. Included with materials selections are recommended corrosion rates to be used for design corrosion allowances for equipment exposed to specific service conditions.

- Recommend suitable courses of action to complete materials selections where available supporting information is insufficient or unavailable.

A course of action has been outlined for generating information previously unavailable to complete the selection of construction materials for the process equipment. The program will be timephased to provide the necessary information sufficiently early for design.

- Identify requirements for verification testing of any questionable areas.

Specifically, a description and a schedule are outlined for any additional verification testing that is required in the remaining package of supporting information.

\subsection{BASIS FOR DEVELOPING MATERIALS SELECTION CRITERIA}

A. review is presented of materials selection requirements found in the FDC, TDP, the American National Standards Institute (ANSI) and American Society of Mechanical Engineers (ASME) codes, and the Department of Energy (DOE) Orders, along with a summary of information on materials selection available from the DWPF and WVDP. The technical, cost and risk factors used in developing materials selection criteria are discussed following this review. 


\subsubsection{Review of the FDC, TDP, and Design Codes, and Supporting Information}

Initially HWVP project personnel, including project Quality Assurance personnel, were solicited for information regarding requirements by, or imposed on, the project that would provide bases for specific materials selection criteria. The outcome of those discussions indicated that no particular procedure or format exists, nor is the requirement for one indicated. Essentially, project review and approval of a compilation of such criteria would perform that function, satisfy project needs, and be in compliance with the FDC.

Based on the above, the FDC was reviewed for requirements and criteria for materials selection to ensure compliance. The FDC provides general guidance for materials selection for the design of equipment, as summarized in Table 3.1. Applicable codes and standards are referenced in the FDC for materials selection, including DOE Orders, ANSI and ASME Standards, etc. These referenced documents were reviewed, and, as in the FDC, no specific materials selection requirements or criteria were identified. The following summarizes information related to materials selection found in these documents.

- ASME/ANSI B31.1 - Pressure and Power Piping: Section 102.4.1 [Corrosion or Erosion Allowances] states that "When corrosion or erosion is expected, an increase in wall thickness of the piping shall be provided over that required by other design requirements. This allowance in the judgement of the designer shall be consistent with the expected life of the piping."

Comment: Guidance on the corrosion or erosion allowance in radioactive areas is to be provided by the HWVP materials evaluation document for HWV remote equipment and piping. Allowances for nonradioactive process equipment will be developed by the AE but will continue to be reviewed as a part of this effort.

Section 123.1 [Acceptable Materials] states that "Materials conforming to specifications listed in Table 126.1 or which have been approved by the procedure established (by this code) are acceptable." 
IABLE 3.1. HWVP Functionał Design Criteria Affecting Materials Selection

FDC

Section

1.2 Scope

1.3.4 Flexibility

1.3.5.6 Component Safety Failure Analysis

3.1 Vitrification Process General Functional

Requirements

3.2.3 Final Feed Makeup and Concentration System

4.1.1 Building Design Life/Physical Design Criteria

4.3.1 Embedded and Remote Piping/ Physical Design Criteria
Statement

The HWVP will use vitrification technology from existing DOE-funded programs to the maximum extent practical based on technical and economic considerations.

The design concept shall facilitate, to the extent practical, modifications required to allow the HWVP to augment and support future DOE programs.

The design shall be such that no single credible component failure will result in unacceptable safety consequences.

Where practicable, replaceable vitrification system process components and equipment shall be designed for a 20-yr life. Nonreplaceable components and equipment shall be designed for a 40 -yr iife. Components such as the melter will not meet this requirement. Current technology indicates that a 2-yr lifetime can be expected for the melter electrodes and refractory. other melter components, such as thermowells and pour spout heaters, may fail more often and must be remotely replaceable without replacing the melter.

The feed can be made up in a vessel that performs other process functions if all other criteria can be met. The feed makeup systen shall be capable of transferring feed to the melter feed system, to the process waste system, or to the initial feed adjustment system.

Components or systems designed for replacement or upgrade in less than 40 yr shall have design lives based on safety, operability, maintainability, and economics. Materials of construction shall be noncombustible and resistant to corrosion.

Piping and piping components shall be made of materials compatible with the operating conditions (i.e., chemical, abrasive) of the vitrification process. Embedded lines carrying abrasive slurries must have adequate backups or be replaceable. 
Comment: Specific materials being evaluated for materials selection are included in the listed materials for this code; thus additional qualification is not required.

Section 124.9 [Deterioration of Materials in Service] states "The selection of materials to resist deterioration in service is generally outside the scope of this code. It is the responsibility of the engineer to select materials suitable for the conditions of operation."

Comment: This is the objective of the HWVP materials evaluation activity.

- ASME/ANSI B31.3 - Chemical and Petroleum Piping: Chapter III Materials, Section 323.1 [Materials and Specification] states "Any material used in pressure containing piping components shall conform to a listed specification..."

Comment: Those materials being evaluated, as above, do conform to listed specifications for those forms commonly used for fabrication. No specification refers to the materials' resistance to deterioration in service, only to their original fabrication.

- ASME Section VIII - Boiler and Pressure Vessel Code: Part UG General Requirements for All Methods of Construction and All Materials, Section UG-4 [Materials] states "Material subject to stress due to pressure shall conform to one of the specifications given in Section II and shall be limited to those that are permitted in the applicable Part of Subsection C....

Material for non-pressure parts, such as skirts, supports, baffles, lugs, clips, and extended heat transfer surfaces, need not conform to the specifications for the material to which they are attached or to a material specification permitted by this Division, but if attached to the vesse? by welding shall be of weldable quality.

It is recommended that the user or his designated agent assure himself that materials used for the construction of the vessels will be suitable for the intended service with respect to retention of satisfactory mechanical properties and resistance to corrosion, erosion, oxidation, and other deterioration during their intended service life." 
Comment: Again the materials under consideration for corrosive service in the remote process equipment and piping are qualified under this code (for fabrication of pressure vessels), so the requirements are met. And it is only a recommendation of the code that the materials be suitably corrosion-resistant. Performance is being established through the efforts of the materials evaluation activity.

- DOE Order 6430.1A - General Design Criteria: In general, without specifically referring to remote processing equipment or piping, several statements in $6430.1 \mathrm{~A}$ regarding construction materials say that "items... shall be specified of materials appropriate for corrosive environments in which they are contained."

Comment: Assuming this requirement would include remote equipment components and piping, the statements are equivalent to those statements in the ASME/ANSI codes that leave the selection of suitable materials up to the engineer, agent, etc.

Summarizing the above, sound engineering judgement based on accepted practice for selecting materials must be employed in the absence of specific requirements and in 1 ieu of rigorous economic comparisons. Thus, a reasonable maximum allowable uniform corrosion rate would be established and materials identified that provide the necessary uniform corrosion resistance and will not fail from localized corrosion (stress corrosion cracking, crevice, pitting). Other technical factors such as accelerated metal loss by erosion, vibration, and flexing must be considered as well as the cost and risk factors involved in selecting materials for HWV. This then creates an objective basis from which to rank candidate materials.

\subsubsection{Technical Rationale for Developing HwVP Materials Selection Criteria}

Savannah River Site (SRS) personnel on a DWPF materials selection committee chose a modification of the above approach and considered a uniform corrosion rate of $<5 \mathrm{mils} / \mathrm{yr}$ as acceptable for materials in the most aggressive environments in the feed preparation and off-gas treatment equipment. A criterion of no evidence of localized corrosion mechanisms was also placed on the search for a suitable material. Corrosion mechanisms include uniform corrosion, stress corrosion cracking, pitting, crevice corrosion, galvanic 
corrosion, and accelerated metal loss due to fluid motion. These mechanisms and their effects on HWV materials selection are summarized in Section 3.2.4.

Although the DWPF and HWVP employ similar processes, differences exist and data from DWPF do not necessarily apply directly to the HWVP. Therefore, the chemical and physical properties (composition, $\mathrm{pH}$, temperature, pressure, physical state, and character) of the materials being processed must be evaluated for HWV in order to specify strength, corrosion allowance, lifetime, and other design factors influencing materials selection. For example, physical requirements for the process (pressure, temperature, contained load, deflection, and maintenance of construction tolerance for fit-up) set the minimum strength and thickness requirements for materials used in process equipment; choices of construction material and corrosion (and erosion) allowances are affected by the chemical characteristics (composition, $\mathrm{pH}$ ) of the materials being processed, their physical state (vapor, liquid, or solid) and temperature; lifetime is usually related to expected commercial use of the product, equipment obsolescence, or changing economic conditions. For HWVP, lifetime has been established by the DOE based on the expected use of the facility (FDC p. 19).

Thus for the HWVP, technical considerations for materials selection focus on areas where corrosion and erosion can occur providing that the materials can otherwise meet the process' physical requirements (pressure, temperature, contajned load). A 5-mils/yr limit for uniform corrosion developed for DWPF is generally more conservative than for other chemical industry standards. It is reasonable, however, for such a facility where replacement, disposal, downtime and other associated costs are so significant. Also, the "no iocalized corrosion" requirement (no stress corrosion cracking, pitting, crevice corrosion) is important because localized corrosion can cause sudden, unpredictable failure and should be avoided where its presence is foreseen. Consequently, these two requirements of $<5 \mathrm{mils} / \mathrm{yr}$ and no localized corrosion are being promulgated as the principal criteria in selecting materials for the HWVP remote equipment and piping.

To establish a limiting uniform corrosion rate provides guidance to the $A E$ for equipment design and also identifies strategies and criteria for 
completing additional testing. Conversations were held with the $\mathrm{AE}^{(a)}$ regarding corrosion allowance for design. A corrosion allowance of $1 / 8$ in. over the 40-yr facility life is being used for piping design without additional requirements. The $A E$ also said that where other factors (erosive slurries, etc.) are involved this corrosion allowance would probably not be used. The $1 / 8 \mathrm{in}$. should be a reasonable allowance for most piping as it converts to roughly $3 \mathrm{mils} / \mathrm{yr}$ and since the 5 -mils/yr criterion allows for worst-case conditions, which include boiling temperatures and erosive conditions.

For many of the HWVP process streams, the range of composition and process conditions, and therefore expected corrosion rates for various construction materials, has not been established. However, from data obtained at DWPF for similar processing, only Hastelloy $\mathrm{C}-276$ and $\mathrm{C}-22$, and Carpenter $20 \mathrm{Cb}-3$ appeared suitable for much of the HWVP process piping and vessel construction. Incone 1690 and Stellite appear to be viable candidates for the melter offgas (MOG) treatment system and other special applications where erosion may be a problem (Bickford, Corbett and Morrison 1986; Bickford and Corbett 1986). Thus the materials selection criteria and the test program strategy and criteria are directed at verifying the process compositions that will be found in HWVP process equipment, their effects on selected construction materials, and any effects of contained erosive materials.

\subsubsection{Cost Rationale for Developing HWVP Materials Selection Criteria}

The initial cost of materials for constructing process equipment is seldom a good indicator for comparing them. Perry (1984, Section 23, p. 14) indicates that as a minimum the items shown in Table 3.2 should be included for comparing various materials for use in chemical process equipment.

A present value analysis at a specific period in time will provide a good measure for evaluating the effect of risk on cost. To use this approach requires prediction of lifetime and the probability for occurrence of unscheduled shutdown from materials failure, which are both uncertainties. Both involve the evaluation of risk and the prediction of failure (to be discussed

(a) Telecon: July 27, 1989, M. R. Elmore, PNL, L. 0lguin, Fluor Daniel, Inc. 


\section{IABLE 3.2. Items To Include in Evaluating Costs of Process Equipment Materials (adapted from Perry 1984)}

Fabricated equipment and piping

Labor to install

Maintenance (amount and timing)

Time and cost required to replace or repair at end of service life Downt ime to replace or repair

Inhibitors, extra control facilities, etc., needed to achieve predicted service life

Time value of money

Factors that affect taxation, depreciation, and tax rates Inflation

in the next subsection). For the HWVP, the factors which impact taxation, depreciation, and tax rates are not applicable. Time value of money and inflation tend to be offsetting and need not be considered in a present-value analysis of materials selection for HWVP.

To illustrate the approach for this type of analysis, the cost of equipment for the slurry receipt and adjustment tank (SRAT) and its associated equipment was selected. The cost differential for selecting Carpenter $20 \mathrm{Cb}-3$ or Hastelloy C-276 was evaluated. For this example, the primary assumption was that the tank will not fail if constructed of either metal but that one or more of the auxiliaries might fail unpredictably and suddenly in 20 years or less if Carpenter $20 \mathrm{Cb}-3$ is used for construction. Such a failure could produce failures in other equipment nearby or later in the process. (The reasons for assuming that Carpenter $20 \mathrm{Cb}-3$ may be a higher risk material than Hastelloy $\mathrm{C}-276$ are discussed later.) Also the use of Hastelloy $\mathrm{C}-276$ to construct HWVP equipment costs at least $20 \%$ more than Carpenter $20 \mathrm{Cb}-3$.

Although a detailed risk analysis was not completed as part of this study, the effect of assuming a chance for a $10 \%, 25 \%, 50 \%$, and 100\% failure of auxiliaries (agitator, condenser, heating coil, cooling coil, sample pump, transfer pump cost) on total cost of these components was addressed. Total replacement cost of auxiliaries was multiplied by the percentage chance of failure, the 
total cost for replacement by a percentage representative of the time and cost needed, and the cost for the downtime expected as a result of the incident was added.

Table 3.3 summarizes the results of this analysis for the SRAT using HWVP cost information for April 1987. The results of this analysis demonstrate that even for a possible $10 \%$ failure of equipment constructed using Carpenter $20 \mathrm{Cb}-3$ (faiTure of a pump causing unexpected plant shutdown for one day) that Hastelloy $\mathrm{C}-276$ is the favored material. Additional evaluations were performed on the slurry mix evaporator (SME), slurry mix evaporator condensate tank (SMECT), melter feed tank (MFT), decontamination waste treatment tank (DWTT), etc., with the same result. This evaluation was completed also for the case where Hastelloy $\mathrm{C}-276$ costs twice as much as Carpenter $20 \mathrm{cb}-3$ but the break-even point is at a failure of about 30 to $40 \%$ of the auxiliaries. The value of this type of analysis has been demonstrated for materials selection in the chemical process industries (Perry 1984) and should be used for the HWVP. The analysis also demonstrates that in the selection process the performance of a construction material for an item of chemical equipment may outweigh the material's cost when life-cycle factors are considered.

\subsubsection{Risk as a Rationale for Developing HWVP Materials Selection Criteria}

Factors such as process economics (primarily cost), operability, maintainability, and end-of-life handling and disposal all must be assessed to predict the risk to plant operation from equipment failure. In addition, the FOC states that major pieces of equipment (such as nonreplaceable components and embedded piping) are to be constructed of materials having 40-yr 1ifetimes and that replaceable equipment shall be designed using materials having a 20-yr life. These are long times for equipment 1 ife under the process conditions anticipated. Thus the primary risks that must be assessed for materials selection are those associated with equipment failure prior to expected lifetime. This is because unexpected equipment failure immediately causes major perturbations in plant economics (cost), operability, and maintainability. 
TABLE 3.3. Cost Comparison for Slurry Receipt and Adjustment Tank Using Carpenter $20 \mathrm{Cb}-3$ or Hastelloy $\mathrm{C}-276$ for Construction (example calculation, in \$K)

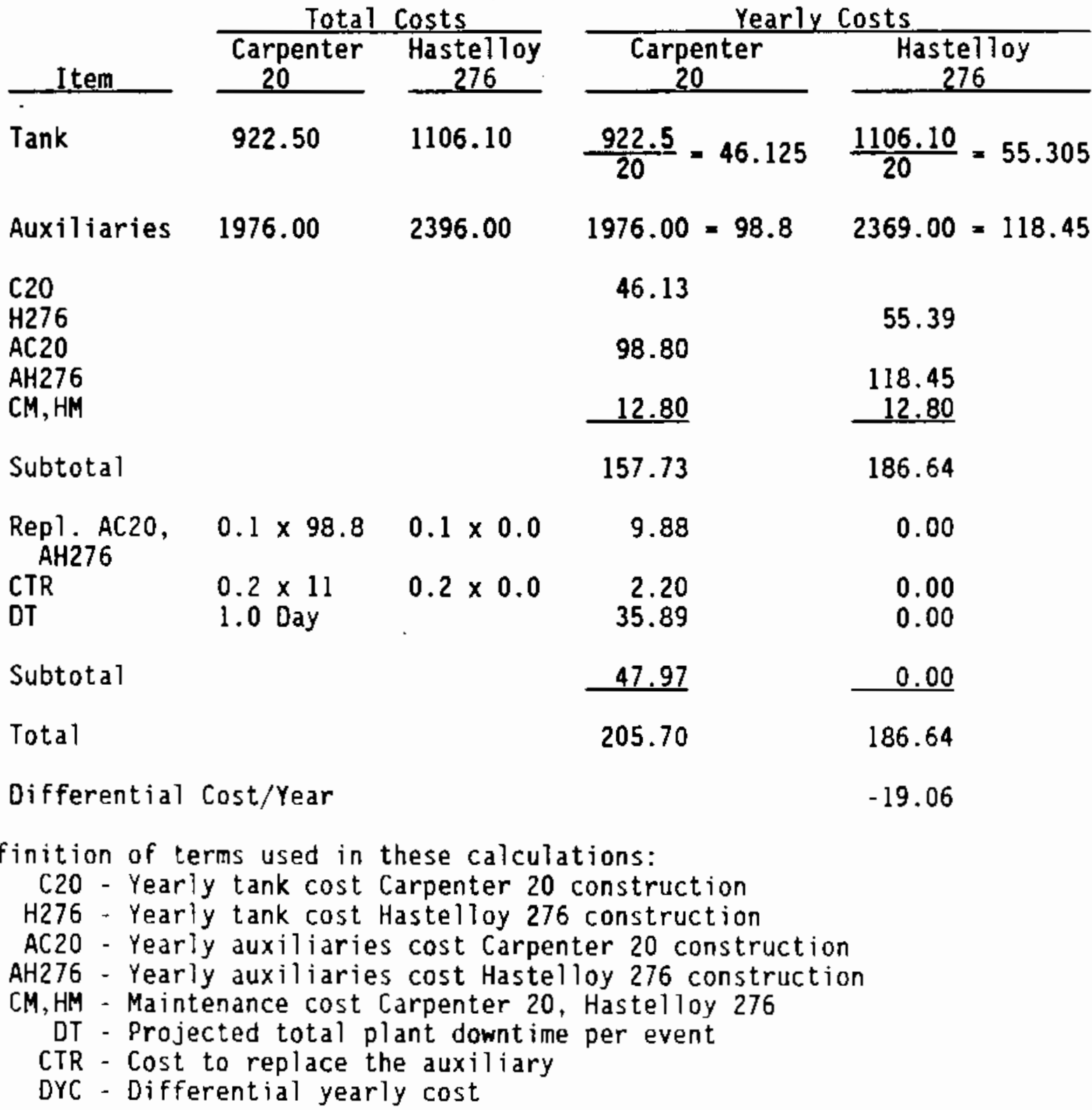

The basic equation used in the evaluation is:

OYC $=H 276+A H 276+H M-C 20-X A C 20-C M-y D T-Z C T R$

Where: $x=$ risk of failure, $y=$ days downt ime associated with replacement of failed equipment, and $z=$ risk factor associated with failure as a $\%$ $(10 \%, 25 \%, 50 \%$, and $100 \%)$ of original total instaliation cost to replace equipment . 
Technical risk is largely related to eliminating the various forms of corrosion that may cause unplanned failure in process equipment and mechanical failure of rotating machinery. Corrosion mechanisms include the localized forms--stress corrosion cracking, pitting, crevice corrosion, galvanic corrosion, and erosion corrosion, which are all more serious than uniform corrosion. All can lead to rapid and unexpected failure of process equipment. Unfortunately, they are all difficult to accurately assess in the laboratory: they often require a long time to show up, and it is hard to match process and laboratory conditions sufficiently to identify them. In the text below, these mechanisms are characterized and discussed as they relate to the possible risk to HWV process equipment and piping.

- Uniform corrosion is the uniform metal loss over the entire surface of the vessel or process piping. The corrosion allowance of $5 \mathrm{mils} / \mathrm{yr}$ covers uniform corrosion. Long-term laboratory testing will provide reasonable data to ensure that sudden, unpredictable failure will not occur because of uniform corrosion.

- Stress corrosion cracking is serious for components that remain under stress, such as field-welded joints and rolled plate, and that are exposed to certain chemical environments. Its major feature is that there is almost no metal loss. However, cracks can propagate at locations that are not properly stress-relieved or that remain under stress in equipment or piping and can cause unanticipated failures (Uhlig 1971).

- Crevice corrosion occurs where crevices are produced under mill scale, nuts, bolts, and other fixtures attached to the equipment wall or at gasketed fittings. Crevice corrosion and pitting are similar (Fontana and Greene 1978) except that the crevice represents a ready-made pit whereas a pit must be initiated as a resuit of particular operating conditions. One form of crevice corrosion occurs where sludges remain in contact with metal surfaces. The latter can be controlled by proper design (eliminating crevices where possible), cleaning, and maintenance (Perrigo and Jensen 1983).

- Pitting, an insidious form of corrosion, is highly aggressive and very localized, and can cause sudden, unexpected failure. Pitting may take years to initiate and may not be observed during laboratory testing, but once it is initiated it can bore a hole through a tank wall (Fontana and Greene 1978). Pitting can usually be controlled by proper choice of construction material, and by control of process conditions. Pitting has been reported at the liquid/vapor interface in certain vessels at DWPF handling liquids similar to those expected in several locations in HWVP. 
- Galvanic corrosion arises because of differences in potential between two dissimilar metals or alloys when they are in contact and immersed in a conductive solution. This form of corrosion can be controlled by choosing metals close together in the galvanic series where needed and ensuring that there is not an unfavorable area ratio (small anode, large cathode).

- Accelerated corrosion due to erosion occurs where fluids containing solids impinge on a flat metal surface and in piping runs at ells, tees, crosses, or bends, or in pipelines with turbuient flow. In vessels, accelerated corrosion occurs near feed inlets and where fluid jets or circulating fluids impinge on the tank walls. The specific mechanism of this form of attack depends upon the fluid velocity and composition, the localized fluid dynamics, and the abrasiveness of the solids entrained in the fluid. Several mechanisms for increased corrosion can be postulated because of the action of flowing fluid. The liquid flow (with or without particles) increases the mass transport from the metal wall to the surface of the oxide film and effectively changes the concentration of the reactive species in contact with the metal. As a result the gradient in the film increases until a new steady state is reached, with a concurrent increase in corrosion rate. Similarly the increased mass transport from the flowing fluid can dissolve the oxide film more rapidly, decreasing its thickness and increasing the corrosion rate. Both mechanisms, because they involve transport of chemical species, are expected to follow the ryles of mass transport with the corrosion rate being a function of Re ${ }^{(0.58)}$ (Vyas 1979). Re is the Reynolds Number and is proportional to the fluid velocity past the surface. The mechanical action of particles that may be entrained in the fluid can affect both mechanisms. Mechanical effects can be minimal and involve the film only or, with sufficiently energetic and/or abrasive particles, can erode the base metal. Mechanical effects are proportional to particle flux.

In piping, erosion corrosion may be absent in straight runs but may be severe at the ells or bends and may cause failures where found. Metal loss can be accelerated in pumps, impellers, and other rotating equipment in slurries by the contained solids as well as by cavitation (destruction of surfaces by the collapse of vapor bubbles in the liquid). These forms of attack are largely controlled by proper choice of materials and by proper design. Control, however, is very difficult where there are boiling fluids.

The use of appropriate laboratory and process testing (e.g., ASTM standard tests such as G31-72) can sometimes identify the risks for failure associated with materials chosen for construction of process equipment and piping by stress corrosion cracking, crevice corrosion, uniform corrosion, and pitting. Miller number measurements for a material (ASTM G75-82) can be used to 
assess the abrasiveness of solids in slurries and to guide the choice of construction materials for these services. A high Miller number indicates a very abrasive material. ASTM G32-77 can be used to evaluate materials for resistance to cavitation.

Once the risks of failure are known, they can be used to more accurately define the cost and technical inputs to the development of materials selection criteria. For example, risk can be translated into probability of failure; probability of failure will have a value of 0 to 1 ; and this value may be used as an appropriate multiplier to replacement cost in economic (cost) evaluations. For HWVP there is a need to minimize risk because the consequence of a major failure will be large, possibly increasing the cell radiological source term. Such an event is unacceptable, and the impact on cost of operation is large. By using the approach outlined above, the risk versus consequence is minimized by examining cost relationships between high performance and reliability versus premature failure. The equipment components for which risk versus consequence (economic consequences) are deemed high enough to merit extensive characterization (lab- or large-scale testing) are shown in the following section, in Table 4.1. 


\subsection{MATERIALS SELECTION STRATEGY}

The following subsections assess the impact of the FDC on materials selection criteria. They also outline the process components and equipment and the chemical environment for the several process areas. Finally, they present a strategy for materials testing and evaluation and a method for quality assurance and documentation.

\subsection{FUNCTIONAL DESIGN CRITERIA AND MATERIALS SELECTION CRITERIA}

As outlined in Section 3.2 above, this document presents results of an evaluation of materials selection needs and of the development of materials selection criteria for the HWVP project. The only specific functional design criteria that influence the materials selection criteria were outlined in Table 3.1. These functional design criteria are not adequate for HWV materials selection purposes. It is clear from Sections 1.3 .4 and 3.2.3 of the FDC that the HWVP design must be flexible to permit later use of the facility to process other feed materials. In addition, although not specifically stated in Section 1.3.5.6, materials must be selected to minimize failure and maximize safety of the design. Additional guidance is given by statements in Section 1.2 of the FDC: "The HWVP will use vitrification technology from existing U.S. Department of Energy (DOE) funded programs to the maximum extent practical based on technical and economic considerations. The Defense Waste Processing Facility and West Valley Demonstration Project programs each provide technology and hardware development that will by used by HWVP." This guidance is significant for materials selection only where processes are enough alike that the information can adequately predict materials performance.

Materials selection criteria found in the various ANSI and ASME codes, DOE Orders, and guidelines referenced in the FDC are too general to be of much value in defining specific materials selection criteria. In summary, sound engineering judgement and a good scientific and technical basis must be used to define a strategy and approach for HWVP materials selection. Thus the following criteria were adopted for project use. 
The following two primary criteria have been used for materials selection within HWVP.

1. Select materials that limit uniform corrosion rates to $5 \mathrm{mils} / \mathrm{yr}$ or less in aggressive HWV environments.

2. Choose materials that show no evidence for localized corrosion for use in HivP.

Criteria 1 and 2, which were used for DWPF and West Valley, define the limits for materials degradation that will be allowed in equipment and piping for HWVP. Since many HWVP process conditions are similar to theirs, they apply to HWVP also. Localized corrosion mechanisms, discussed in Section 3.2.3, often result in more serious problems than does uniform corrosion.

The following secondary selection criteria are given as additional necessary guidelines to ensure acceptable material selections for the HWVP process equipment and piping:

A. Minimize the number of alloys used.

Flexibility requires that as much of the equipment as practicable needs to be interchangeable. This approach maximizes interchangeability of process equipment and promotes good quality control in installation and field repair. Minimizing the alloys used for constructing process equipment also reduces the possibilities of gaivanic attack and sudden unexpected failure.

B. Choose materials that withstand the chemical and physical process environment without the use of corrosion inhibitors.

This criterion is consistent with DOE Orders $5820.2 \mathrm{~A}$ and 5400.1 to develop means for waste minimization. The use of chemicals to inhibit corrosion may increase the waste that must eventually be processed for storage and disposal. Moreover, corrosion inhibitors are seldom practicable for single-pass systems.

c. Identify project-related requirements (and changes that occur in these requirements during design) for specific materials selections; relate these requirements to equipment, piping, and other construction items; and select materials that meet design needs.

Because specific materials selection criteria are not specified in baseline documents such as the FDC or TDP, a continuing review of project requirements is needed to ensure that materials selection criteria are appropriate for the project. Operating conditions (duty cycles) for specific process equipment of ten change during process design; since these changes can affect materials selections, 
they need evaluation. Continual evaluation of technical and quality assurance requirements are a part of this review process and meet the need identified in the FDC that HWVP be flexible. Where changes in materials selection criteria and guidelines are required, new standards will be adopted and old ones rescinded.

D. Thoroughly evaluate the process to identify the conditions that can produce equipment failure.

To select materials for constructing HWVP process equipment appropriate for the anticipated exposures, careful evaluation of the conditions and materials is needed at each process location. Evaluation is necessary for the oxidizing or reducing environments, ionic species and concentration, reaction rates, fluid velocities and abrasiveness of entrained particles, phase characteristics, temperature, pressure, condensables, contaminants, etc., and their effects on the construction materials proposed. As identified in the FDC, the probability exists that various other wastes will be processed later. Differences in the characteristics of these future wastes that may affect the materials proposed should be assessed, to the extent possible, before detajled design is completed. The effect the changed processing parameters (composition, temperature, etc.) may have on construction materials needs to be defined.

E. Make material selections where adequate supporting information, test results, or other bases for sound engineering judgement exist.

Materials selection made on the basis of this criterion must be supported by adequate documentation. This shall include information on expected corrosion rates and resistance to localized corrosion and be based on acceptable and reproducible test methods. If available, the test method or procedure used to develop the data shall be included. When adequate supporting information is not available, recommend courses of action to complete materials selection. These are to include: the testing, suggested test methods, test schedule, supporting documentation requirements, and cost and schedule needs to obtain the information. Where needed, the program should be time-phased to provide the necessary information to design in a timely manner.

F. Evaluate and rank materials as to their ease of fabrication, availability of mill forms, and mechanical and physical properties.

Selection of a construction material that resists failure due to corrosion means that its availability must be considered as well as its strength and other mechanical characteristics. Assuming the material meets other technical materials selection requirements, it will need to be available in appropriate mill forms (sheet, plate, bar, tube, or pipe), and be fabricated cost effectively into the 
piece of equipment. Ability to fabricate (cutting, forming, casting, welding, etc.) needs to be considered.

G. Select materials that meet the above technical criteria on the basis of risk of failure that will produce exposure to workers or release hazardous chemicals or radioactivity from HWVP, and on the bas is of cost.

Sections 3.2.2 and 3.3.3 discuss the cost and risk factors associated with equipment failures. Since the risk of equipment failure can be quantified most easily within a cost analysis, the approach identified in Section 3.2.2 will characterize the effect of risk on cost and will provide appropriate guidance for materials selection where two or more materials meet minimum technical requirements but differ in cost.

\subsection{COMPONENTS AND EQUIPMENT FOR PROCESS AREAS}

In addition to determining a reasonable performance limit (5 mils/yr), engineering judgement must be employed to establish a reasonable level of detail in specifying materials for particular applications. DWPF materials selection efforts centered around identifying one materiat that is compatible with conditions in both the feed preparation and off-gas treatment equipment. By maximizing interchangeability of components, Savannah River Laboratory (SRL) personnel have indicated that having one reference material limits the chance for material mixups and reduces inventory requirements for spares. A similar approach is recommended for HWVP.

\subsubsection{Process Equipment Listing}

Table 4.1 summarizes the equipment for which information is required from the project to identify suitable construction materials. Figure 4.1 is a block diagram that describes the process; Figure 4.2 depicts the layout of the canyon. Reference processing and compositional information for various locations in the process as developed from DWPF information is found in the references (for DWPF: Corbett, Bickford, and Morrison 1986 and Bickford and Corbett 1984; for HWVP: HWVP FDC). The melter and melter off-gas line, however, are equipment not listed in Table 4.1 for which fabrication materials will have to be selected. They are discussed later. As the equipment for decontaminating the canister by frit-blasting will be the same as for DWPF, it is not addressed in this report. 
TABLE 4.1. HWVP Chemical Process Equipment Requiring Materials Selection(a)

\begin{tabular}{|c|c|c|c|c|c|c|c|c|c|c|c|c|}
\hline \multirow[b]{2}{*}{ Component } & \multirow[b]{2}{*}{$\underline{\text { RLST }}$} & \multirow[b]{2}{*}{$\underline{W T}$} & \multicolumn{3}{|c|}{$\begin{array}{l}\text { Slurry } \\
\text { Processing }\end{array}$} & \multicolumn{2}{|c|}{$\begin{array}{r}\text { Melter } \\
\text { Off Gas } \\
\end{array}$} & \multicolumn{5}{|c|}{$\begin{array}{l}\text { Condensed Vapor Recovery } \\
\text { and Waste Handling }\end{array}$} \\
\hline & & & SRAT & SME & MFT & $\underline{\underline{S B S}}$ & HEME & $\underline{F F T}$ & SMECT & DUTT & RWCT & WAT \\
\hline Vessel & $x$ & $x$ & $x$ & $x$ & $x$ & $x$ & $x$ & $x$ & $x$ & $x$ & $x$ & $x$ \\
\hline Transfer Pump & $x$ & $x$ & $x$ & $x$ & $x$ & jet & jet & $x$ & $x$ & $x$ & $x$ & $x$ \\
\hline Sample Pump & $x$ & $x$ & $x$ & $x$ & $x$ & $x$ & & $x$ & $x$ & $x$ & $x$ & $x$ \\
\hline Agitator & $x$ & $x$ & $x$ & $x$ & $x$ & & & $x$ & & $x$ & $x$ & $x$ \\
\hline Leve1 Diptube & $x$ & $x$ & $x$ & $x$ & $x$ & $x$ & $x$ & $x$ & $x$ & $x$ & $x$ & $x$ \\
\hline Thermowe 11 & $x$ & $x$ & $x$ & $x$ & $x$ & $x$ & & $x$ & $x$ & $x$ & $x$ & $x$ \\
\hline Coil Assembly & $x$ & & $x$ & $x$ & $x$ & $x$ & & $x$ & & $x$ & $x$ & \\
\hline Condenser & & & $x$ & $x$ & & & & & & $x$ & $x$ & \\
\hline Filter & & & & & & & & & & & $x$ & \\
\hline
\end{tabular}

(a) See "Acronyms" at front of this report.

\subsubsection{Process Requirements}

Construction materials for the HWVP must be selected with special care because its envelope of feed component concentrations is different from the DWPF's and unexpected components in waste feeds could adversely affect materials performance. Some examples of differences are that fluoride concentrations in some wastes processed in HWVP may be two orders of magnitude greater than those processed in DWPF. Other differences are that the HWVP melter offgas treatment system is based on the WVDP design and that the DWPF design has no process waste treatment system. Therefore, a larger variability in waste stream components from recycling and equipment decontamination is expected.

A reference feed composition (Table 4.2) is specified in the HWVP TDP based on limited tank farm characterization and on various PUREX and waste treatment simulations. Based on corrosion information in the literature cited, chloride, fluoride, sulfate, nitrate, nitrite, and formate-particularly in the acidic environments expected to be found in HWV process equipment--would be the major contributors to corrosion-induced failure of construction materials. Other possible components that may contribute to corrosion include transition metal ions. Also physical conditions, 


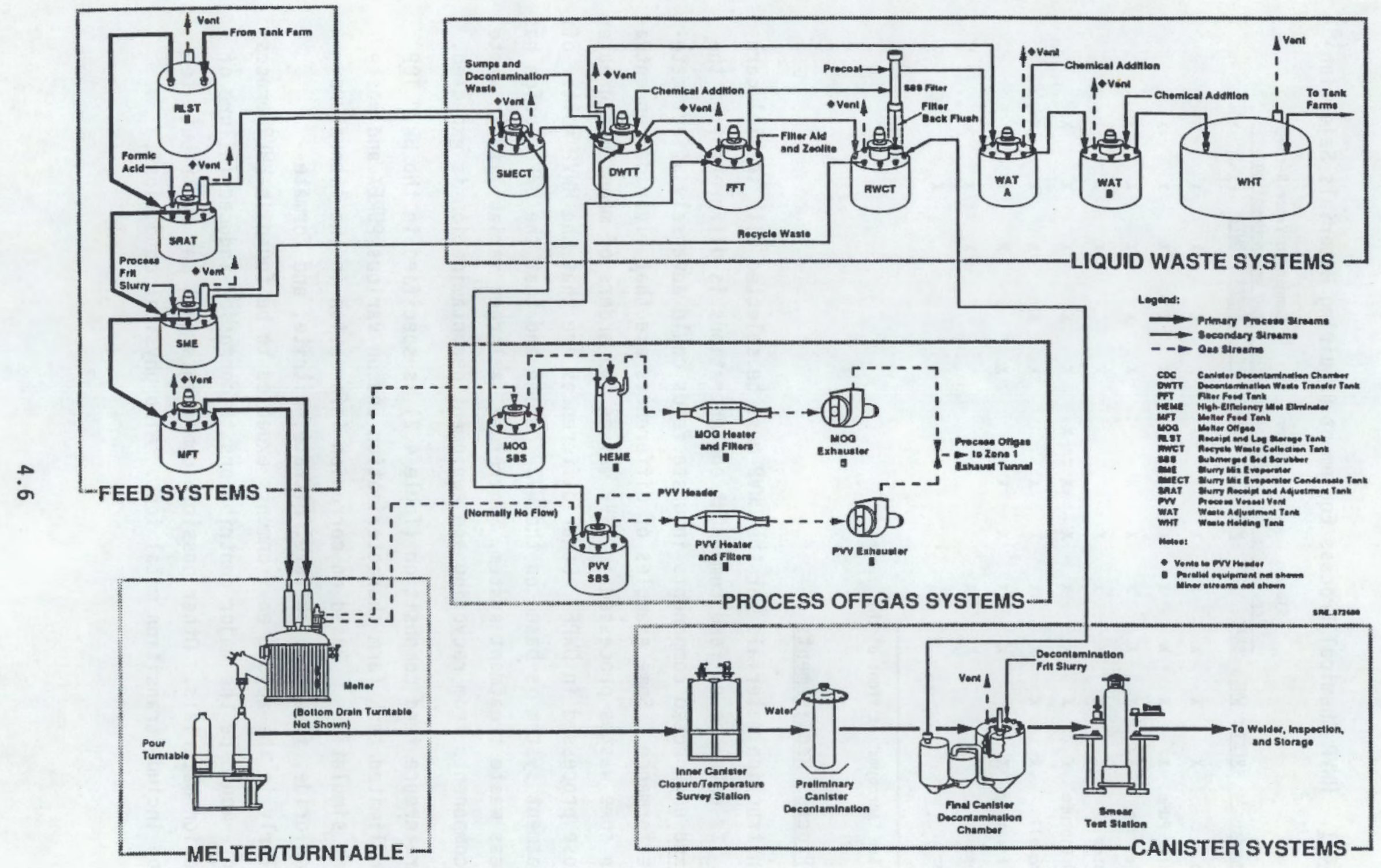

FIGURE 4.1. Basic Flow Diagram for HWVP Process 


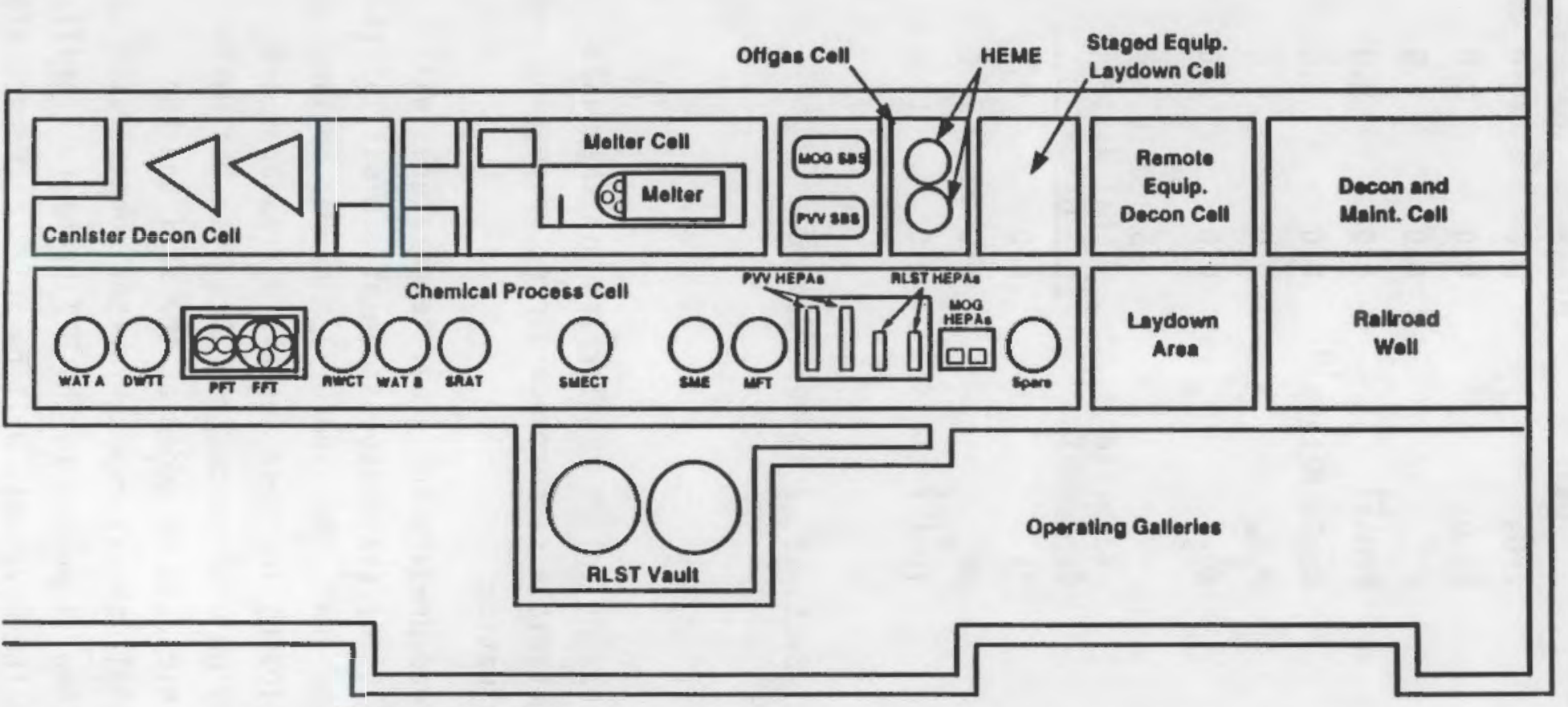

DWTT = Decontemination Wasto Treatment Tank

FFT a Fillor Foed Tank

HEME a High-Eitticiency Mist Ellminator

HEPA = High-EHiclency Particulate Air

MFT = Melter Faed Tank

MOG = Molter Ottgas

PFT = Precoal Foed Tank

PVV = Process Vossel Vent

ALST = Recalpt and Lag Storage Tank

AWCT = Recycle Waste Colloction Tank

SBS a Submerged Bed Scrubber

SME = Slumy Mix Evaporator

SMECT = Slumy Mix Evaporator Condenser Tank

SRAT = Slumy Recaipt and Adjustment Tank

WAT = Watto Adjustment Tank

FIGURE 4.2. Basic Arrangement of HWVP Cells 
TABLE 4.2. HWVP Reference Feed Compositional Range (oxide basis) (a)

\begin{tabular}{|c|c|c|c|c|c|}
\hline \multirow{2}{*}{$\begin{array}{c}\text { 0xides to } \\
\text { HWVP }\end{array}$} & \multicolumn{2}{|c|}{$\begin{array}{c}\text { Wt\% of Total } \\
\text { Nonvolatile Oxides }\end{array}$} & \multirow{2}{*}{$\begin{array}{c}\text { Oxides to } \\
\text { HWVP }\end{array}$} & \multicolumn{2}{|c|}{$\begin{array}{c}\text { Wt\% of Total } \\
\text { Nonvolatile Oxides }\end{array}$} \\
\hline & Minimum & Maximum & & Minimum & Maximum \\
\hline $\mathrm{Al}_{2} \mathrm{O}_{3}$ & 2.0 & 26.0 & $\mathrm{ZrO}_{2}$ & 0.0 & 40.0 \\
\hline $\mathrm{BaO}$ & 0.0 & 20.0 & $\mathrm{Cr}_{2} \mathrm{O}_{3}$ & 0.0 & 2.0 \\
\hline $\mathrm{CaO}$ & 0.0 & 20.0 & $F$ & 0.0 & 6.9 \\
\hline $\mathrm{CdO}$ & 0.0 & 10.0 & $\mathrm{FPO}^{(\mathrm{b})}$ & 0.0 & 5.0 \\
\hline $\mathrm{Fe}_{2} \mathrm{O}_{3}$ & 8.0 & 60.0 & Noble Metals $(d)$ & 0.0 & 1.0 \\
\hline$(\mathrm{La}, \mathrm{Nd})_{2} \mathrm{O}_{3}$ & 0.0 & 8.0 & $\mathrm{P}_{2} \mathrm{O}_{5}$ & 0.0 & 4.0 \\
\hline $\mathrm{MnO}_{2}$ & 0.0 & 20.0 & $\mathrm{SO}_{3}$ & 0.0 & 2.0 \\
\hline $\mathrm{MoO}_{3}$ & 0.0 & 8.0 & & $1 \mathrm{~b} / 1$ & 16 of \\
\hline $\mathrm{Na}_{2} \mathrm{O}$ & 4.5 & 22.0 & $\begin{array}{l}\text { Volatile } \\
\text { Components } \\
\end{array}$ & $\begin{array}{r}\text { Tota } \\
0 \\
\end{array}$ & $\begin{array}{l}\text { aste } \\
\text { es }\end{array}$ \\
\hline $\mathrm{NiO}$ & 0.0 & 8.0 & $\mathrm{Cl}$ & 0.0 & 0.3 \\
\hline $\mathrm{SiO}_{2}$ & 0.0 & 17.5 & $\mathrm{NO}_{\mathrm{x}}$ & 0.0 & 36.0 \\
\hline $\begin{array}{l}\mathrm{TiO}_{2} \\
\mathrm{U}_{3} \mathrm{O}_{8}\end{array}$ & $\begin{array}{l}0.0 \\
0.0\end{array}$ & $\begin{array}{r}4.0 \\
32.0\end{array}$ & $\operatorname{TOC}^{(c)}$ & 0.0 & 11.0 \\
\hline
\end{tabular}
(a) HWVP Technical Data Package, Sect. 13, Item 200, Rev.4B.
(b) $\mathrm{FPO}=$ fission product oxides.
(c) $\mathrm{TOC}=$ total organic carbon.
(d) $\mathrm{PdO}, \mathrm{Rh}_{2} \mathrm{O}_{3}, \mathrm{Ru}_{2} \mathrm{O}_{3}$.

particularly heat and the abrasiveness of solids in slurries (in the wasteadded frit), affect corrosion and materials performance during processing and must be considered in materials evaluation.

For process equipment in the feed preparation area, temperatures will range from ambient to about $358^{\circ} \mathrm{F}\left(181^{\circ} \mathrm{C}\right.$ ) (saturated steam at $150 \mathrm{psi}$ ) at the surface of steam-heating coils in the SRAT, SME, and DWTT. Normal boiling temperatures will be around $217^{\circ} \mathrm{F}\left(103^{\circ} \mathrm{C}\right)$ in these vessels. Pressures are expected to be near ambient. Slurry $\mathrm{pH}$ will range from 13.2 when the waste enters the SRAT to pH 3-6 after formic acid is added at the SRAT and the slurry is concentrated. From the SRAT, the slurry is further concentrated in the SME, where frit is added, and then is pumped to the MFT prior to vitrification in the melter. Off gas from these vessels will be acidic. Condensates 
will be recovered in the SMECT and then transferred to the DWTT. Other off gas from the SRAT and the SME will be sent to the process vessel vent header. The bottoms from the DWTT will be recycled to the recycle waste collection tank (RNCT) after chemicals and other process wastes are added. Condensate from the DWTT will be sent to the waste adjustment tank (WAT) and mixed with filtrate from the submerged bed scrubber (SBS) filters and will be sent to the waste hold tank (WHT) after chemical addition.

Vitrification takes place in the melter at $\sim 2100^{\circ} \mathrm{F}\left(-1150^{\circ} \mathrm{C}\right)$. During vitrification, reaction of the slurry produces molten glass, combustion of organic species, vaporization of volatiles and semivolatiles, and decomposition of the chemical species. Off gases from the melter will be quenched to produce acidic condensates ( $\mathrm{pH}-1.0$ to 2.0 ) containing sulfates, halides, nitrates, and other chemical species. Melter off-gas (MOG) temperatures are expected to remain above the dew point $\left(-220^{\circ} \mathrm{F} /-105^{\circ} \mathrm{C}\right)$ until the melter off gas is quenched in the MOG/SBS. After quenching, the off-gas temperature will remain low $\left(<200^{\circ} \mathrm{F} /<95^{\circ} \mathrm{C}\right)$ as the $(M O G)$ condensates are cycled through the SBS filter feed tank (FFT), and SBS filter. Sludge from the SBS filter is mixed with DWTT bottoms in the RWCT and is fed back to the SME. As mentioned, filtrate from the SBS filter is sent to the WAT.

\subsection{STRATEGY FOR MATERIALS TESTING AND EVALUATION}

To develop a strategy for materials testing for HWVP, the materials testing completed for similar projects (such as the DWPF and WVDP) was reviewed. Since some corrosion testing has been performed for the HWVP, those results also are given. (See Section 5.1.3 for a review of HWVP materials testing.) Using the information developed in the HWVP testing and the review of the DWPF and WVDP information, a strategy for future HWVP materials testing is presented. Materials testing has been completed for the WVDP, and West Valley Nuclear Services shared the information with PNL.

For the DWPF, SRL personnel have provided information to HWVP and published data covering materials testing completed at their laboratories for DWPF (Baxter 1983; Bickford and Corbett 1984; Bickford, Corbett and Morrison 1986; Bickford and Corbett 1986). In addition, a preliminary evaluation of 
materials selection was completed in 1986, and screening and coupon testing for HWVP have been completed at Pacific Northwest Laboratory. Also, in some pilot-scale melter tests completed at SRL during 1982-83, pitting was noted in the off-gas treatment 1 ine at points where the off gas reaches dew point. This phenomenon, called dew point corrosion, is well documented (Agarwal, Hodge and Storey 1985; Dene 1985). These reports, data, and information summaries have been evaluated for any information applicable to a strategy to test materials and evaluate future materials needs for the HWVP. Modified ASTM test procedures were used for laboratory testing completed at SRL for DWPF (Bickford, Corbett and Morrison 1986) and for the WVDP.

Materials testing and evaluation completed at PNL has also used ASTM and modified ASTM test procedures for coupon testing. To establish that the documentation for the testing would ensure reproducibility, test plans were prepared and were subjected to technical review and management approval processes. For the HWVP, test plans for materials selection have been prepared, and the test results have been issued at regular intervals.

Using the processing information described in Section 4.2.2 together with other information on anticipated waste stream compositions and process conditions, HWVP staff evaluated the applicability of DWPF materials selection studies to HWVP. From these evaluations, the following preliminary list of reference materials was developed using DWPF test information and input from SRL and materials suppliers and comprised those materials initially screened:

- 304-L stainless steel

- Carpenter $20 \mathrm{Cb}-3$

- Hastelloy C-276

- Haste1loy C-22
- Hastelloy G-3

- Titanium Grade 7

- Titanium Beta-C

- ALLCORR.

For the HWVP, test solution compositions were developed and prepared for use in initial screening to identify the most corrosive environments expected in the HWVP. These solutions have been used in accelerated tests for evaluating materials under those conditions. For example, testing has used conditions of boiling formated feed slurry (simulating the SRAT) and boiling simulated off-gas condensate chemically adjusted for recycle of transuranics 
(simulating what was considered to be a worst-case scenario for the DWTT). More detail on completed HWVP materials testing is described in Section 5.0.

The testing since 1987 has demonstrated that of the alloys tested, only Hastelloy C-276, Hastelloy C-22, and Carpenter $20 \mathrm{Cb}-3$ are viable choices for HWVP process vessels. In addition, alloys such as Inconel 690, ALLCORR, and Stellite 6-B are recommended for specific applications such as in the melter off-gas line (Inconel 690) or wherever abrasive slurries are anticipated (Stellite 6-B).

\subsection{QUALITY ASSURANCE AND DOCUMENTATION}

To ensure that the above materials selection criteria and strategy for materials testing and evaluation meet the needs of the HWVP, DOE and PNL quality assurance and documentation procedures identified in Ryder (1989) are being used for all tests and evaluations. The procedures outlined by appropriate DOE and PNL quality assurance plans provide for test plan preparation, peer review, and management approval prior to testing and evaluating materials in the laboratory or in pilot-plant demonstrations. Materials selections made on the basis of open literature must satisfy quality assurance requirements for the project. 




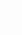




\subsection{MATERIALS TESIING}

Laboratory testing and other materials evaluations have been completed at DWPF, WVDP, and HWVP. Information developed in these studies has been reviewed for applicability to HWVP. The results of this review are presented in subsections 5.1 and 5.2. The final subsection, 5.3, sumarizes the information pertinent to HWVP materials selection. Additional information from PNL screening experiments is tabulated in Appendix A.

\subsection{LABORATORY TESTING}

Available information from laboratory testing and other materials evaluation that has been conducted for the DWPF, WVDP, and HWVP has been reviewed. Laboratory testing for DWPF has been extensive, and those results that are specific to the HWV materials selection process are presented. Information on laboratory materials testing was shared with PNL in April 1990. For WVDP, work was limited to two test environments that represent the feed preparation solution and off-gas condensate. WVP test solutions contained chioride, fluoride and mercury concentrations within the envelopes used for DWPF and HWVP materials testing, but nitrate concentrations were much higher. Additional laboratory testing was completed for HWVP to confirm the results of the SRL testing that are pertinent to the HWVP. A summary of the candidate alloys tested for DWPF is found in Table 5.1. Several alloys evaluated for DWPF were tested also for HWVP or WVDP, and these are identified. Two titanium alloys are included in Table 5.1 that were not tested for DWPF.

\section{5.l.1 Laboratory Testing for DWPF}

Laboratory test information for the DWPF has been summarized(a) (Corbett, Bickford, and Morrison 1986; Bickford and Corbett 1984). The direct application of DWPF laboratory test data to the HWVP is tempered by the following considerations: 1) solutions used in DWPF testing have included mercury,

(a) Meetings and telecons with D. F. Bickford, SRL, about the status of SRL'S materials evaluation program for DWPF. Savannah River Laboratory, Aiken, South Carolina (Technical Exchange Meeting: October 15, 1986; Telecons: November 7, 1985, Apri1 14, 1986). 
TABLE 5.1. Chemical Composition of Alloys Tested at SRL (Corbett, Bickford, and Morrison 1986)

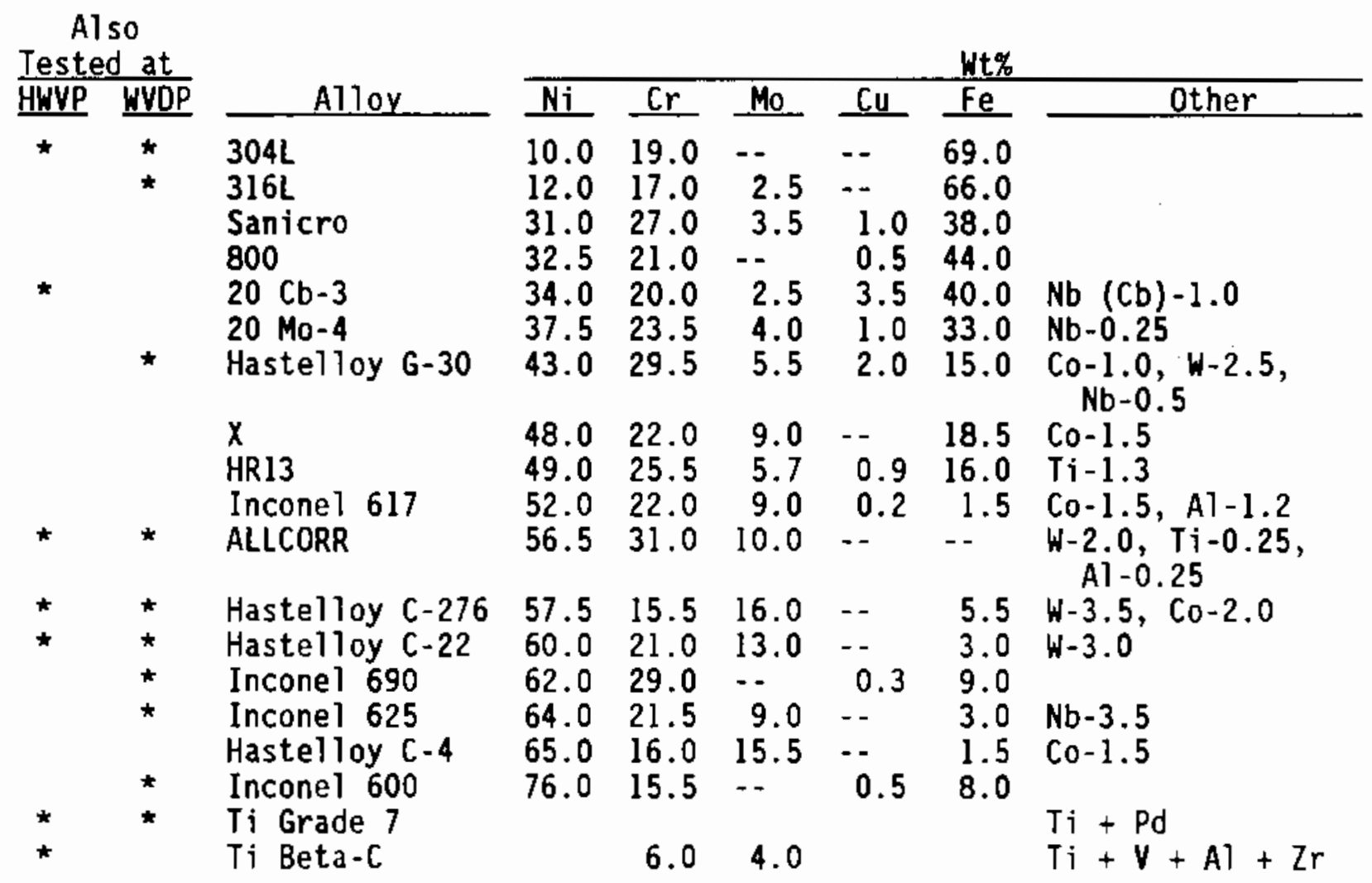

particularly mercury chloride, which has been reported by the DWPF to cause pitting in Carpenter $20 \mathrm{Cb}-3$, and 2) fluoride concentrations in DWPF test solutions are much lower than those expected in HWVP process streams. Iodide was included in DWPF testing but was not a component of simulated HWVP solutions. DWPF personnel believed that, although iodide was added to their test solutions, it does not present a concern from a materials standpoint.

In reviewing the materials requirements for the feed preparation system (SRAT, SME, and MFT) for DWPF, particular attention was given to the criteria to minimize the number of alloys chosen and to maximize the interchangeability of equipment. Thus it was decided to construct the SRAT, SME, and MFT and their components from the same material to maximize their interchangeability. This decision means that their construction materials must be resistant to the worst-case corrosion and accelerated metal loss because abrasive conditions might be expected at some locations in the feed preparation system. 
Additional concerns relate to the higher solids (glass frit) concentrations in the SME and MFT and the abrasion resistance needed for agitators and pump impellers to minimize accelerated corrosion from abrasive slurries.

At DWPF an interactive process was used for materials selection in which 304-L stainless steel was initially selected as the reference material for slurry treatment and off-gas equipment. All alloys in Table 5.1 except the two titanium alloys were tested for DWPF. Testing was completed for one to two weeks at concentrations higher than anticipated and under submerged, vapor space and condensing conditions. Specific concentrations for the testing were selected by obtaining input from individuals familiar with the DWPF and estimating stream compositions throughout the process. (See Appendix A for chemical concentrations used in screening tests.) For preliminary scouting experiments and later verification tests, the conditions shown in Table 5.2 were identified from pilot-scale operations for the SRAT, SME, and off-gas treatment system (Bickford and Corbett 1984). When laboratory testing demonstrated that 304-L stainless steel was unsatisfactory, Carpenter $20 \mathrm{Cb}-3$ was specified as the reference material until it also proved unsatisfactory in laboratory testing. Hastelloy $\mathrm{C}-276$ was then specified as the reference

IABLE 5.2. Conditions Chosen for SRL Preliminary Scouting (Pre.) and Verification (Ver.) Testing (Corbett, Bickford, and Morrison 1986)

\begin{tabular}{|c|c|c|c|c|c|c|}
\hline \multirow{2}{*}{$\frac{\text { Component, }}{\text { ppm (c) }}$} & \multicolumn{2}{|c|}{$\operatorname{SRAT}^{(a)}$} & \multicolumn{2}{|c|}{$\operatorname{SME}^{(a)}$} & \multicolumn{2}{|c|}{ Off-Gas (b) } \\
\hline & Pre. & Ver. & Pre. & Ver. & Pre. & Ver. \\
\hline $\mathrm{Cl}^{-}$ & 20,000 & 3,800 & 20,000 & 3,800 & 20,000 & 2,500 \\
\hline$F^{-}$ & 2,300 & 400 & 2,300 & 400 & 2,300 & 300 \\
\hline $\mathrm{SO}_{4}{ }^{=}$ & 300 & 60 & 300 & 60 & 1,400 & 800 \\
\hline $\mathrm{NO}_{3}^{-}$ & -- & $\cdots$ & $\cdots$ & - & 0 & $0 ; 6,000$ \\
\hline $\mathrm{Hg}^{+}$ & 28,000 & 10,600 & 10,000 & 16,000 & 4,500 & 1,000 \\
\hline $\mathrm{pH}$ & $4 ; 6$ & $3.2 ; 6$ & $4 ; 6$ & $3.2 ; 6$ & $1.6 ; 6$ & $2.2 ; 6.9 ; 12$ \\
\hline Temp., ${ }^{\circ} \mathrm{F}$ & Boil & Boil & 203 & 203 & $104 ; 194$ & $104 ; 140 ; 194$ \\
\hline
\end{tabular}

(a) The pH was adjusted with formic acid.

(b) The pH was adjusted with sulfuric acid.

(c) For this report the difference between mass basis and volume basis for concentrations is considered negligible. 
demonstrated that 304-L stainless steel was unsatisfactory, Carpenter $20 \mathrm{Cb}-3$ was specified as the reference material until it also proved unsatisfactory in laboratory testing. Hastelloy $\mathrm{C}-276$ was then specified as the reference material. Carpenter $20 \mathrm{Cb}-3$ was rejected because mercury and mercury compounds in the feed and off-gas systems caused the intergranular attack and pitting of this alloy. (a)

Additional testing for DWPF demonstrated that Hastelloy C-276 may not be entirely satisfactory for the melter off-gas $l$ ine and the off-gas quencher in DWPF because of pitting from dew point corrosion in the quencher. Inconel 690 was then selected for the melter off-gas line to the quencher, and ALLCORR was suggested for the ejector venturi scrubber, with Hastelloy C-276 as a backup alloy. However, since ALLCORR is a new alloy that may not be available for construction of the ejector venturi scrubber, the DWPF materials selection committee recommended Hastelloy $\mathrm{C}-276$ as the reference alloy for this application. (a)

Section 5.3 summarizes the results of DWPF materials selection that are applicable to HWV materials selection efforts.

\subsubsection{Laboratory Testing for WVDP}

Candidate materials were assessed for use in the WVDP. West Valley Nuclear Services informed PNL personnel in discussions that the program objective was to evaluate candidate construction materials for the feed preparation and off-gas processing systems. Specimens of the alloys identified for WVDP in Table 5.1 were evaluated for both uniform corrosion and localized corrosion,

The approximate composition of the simulated feed preparation slurry and off-gas condensate used in the WVDP testing is found in Table 5.3. Three types of coupons (welded, crevice, and U-bend) were evaluated for weight loss,

(a) Telecon with D. F. Bickford, SRL, about SRL's materials evaluation program for DWPF, Savannah River Laboratory, Aiken, South Carolina, November $7,1985$. 


\section{TABLE 5.3. Approximate Compositions of Solutions for WVDP Tests}

\begin{tabular}{|c|c|c|}
\hline Constituent & Feed Prep, (a) ppm & Off Gas, (b) \\
\hline $\mathrm{Cl}^{-}$ & 350 & 1,500 \\
\hline$F^{-}$ & 2,000 & 9,000 \\
\hline $\mathrm{Hg}$ & 15 & 60 \\
\hline $\mathrm{SO}_{4}=$ & 200 & 0 \\
\hline $\mathrm{PO}_{4}^{3-}$ & 4,500 & 125 \\
\hline $\mathrm{NO}_{3}^{-}$ & 205,000 & 190,000 \\
\hline $\mathrm{pH}$ & $<1$ & $<1$ \\
\hline
\end{tabular}

(a) Solution at boiling.

(b) Maintained at $\sim 80^{\circ} \mathrm{C}$.

pitting, selective corrosion at or adjacent to welds, stress corrosion cracking, end grain corrosion, and intergranular attack. Specimens were suspended as follows:

- completely in the Tiquid,

- completely in the vapor, and

- completely in the condensate.

A11 coupons were removed from the test solutions after 2 weeks' exposure, weighed, and examined, and most were returned to the kettles. One U-bend and one crevice corrosion specimen for each metal were not returned after the 2-week exposure period but instead were destructively examined for uniform or localized corrosion. Then the test was continued for 6 more weeks. All specimens were cleaned, weighed, examined visually, and photographed, and representative specimens from the 8 -week tests were destructively evaluated for depth of attack as well as changes in surface morphology.

The results of the analysis of test specimens for uniform and localized corrosion are given in Table 5.4. Only Hastelloy C-22 performed well in the two test solutions. Titanium Grade 7 performed well in the feed preparation test solution but did not perform well in the off-gas solution. Hastelloy 
TABLE 5.4. Results of WVDP Corrosion Evaluations Shared with PNL (a)

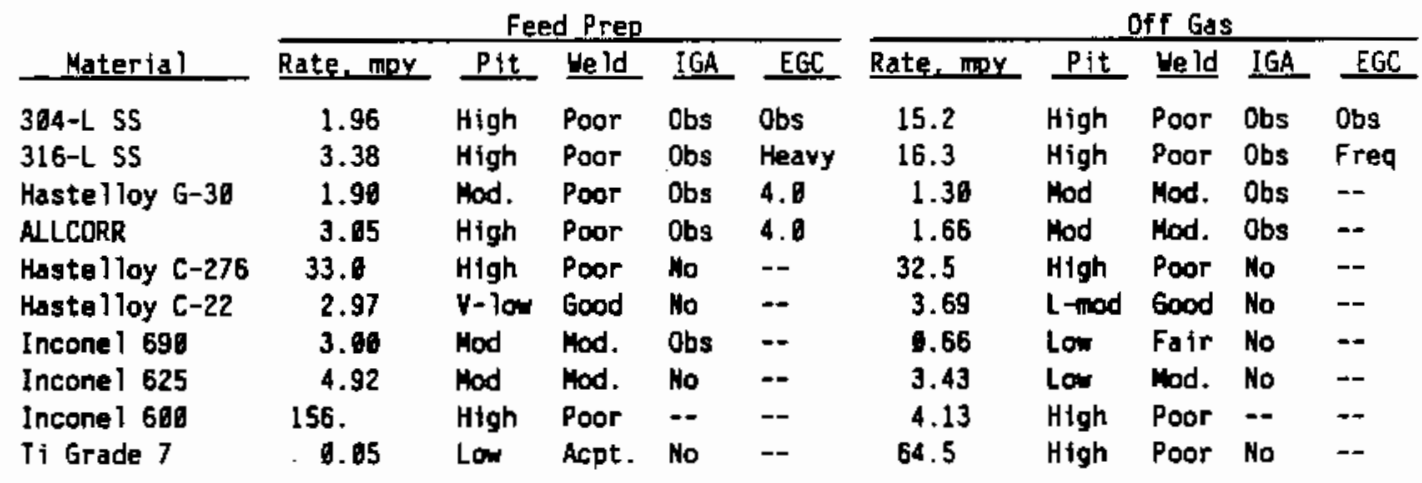

(a) For test conditions refer to Table 5.3. Pit = pitting, probability (high, L-mod = low mod, $V$-low $=$ very low); Weld = weld attack; $I G A=$ intergranular attdck; obs = observed; EGC = end grain corrosion.

C-276 bolts and washers were used to stress the U-bends, and nearly all failed or were so badly corroded that the U-bends were useless for determining stress effects on corrosion. Hastelloy C-276 and Inconel 600 had corrosion rates over 10 mpy, and coupons of both alloys were severely pitted and showed other significant localized attack.

Overall the conclusions of the work are that titanium Grade 7 is the best material for construction in the feed preparation area, followed by Hastelloy $\mathrm{C}-22$. For the off-gas treatment system Inconel 690 is best, followed by Hastelloy C-22. For WVDP Hastelloy C-276 is unacceptable.

\subsubsection{Laboratory Testing for HWVP}

Results of HWVP laboratory testing at PNL are summarized in this section.

Initial laboratory screening tests were performed to evaluate construction materials that would contact corrosive environments in the feed preparation and off-gas equipment. This work had two phases:

- Conduct preliminary scoping tests with all initial candidate materials. The results of these scoping tests were to be used to identify a 1 imited number of the initial candidate materials found suitable for additional testing. Scoping tests included standard immersed coupon tests and potentiodynamic electrochemical tests. 
- Perform additional testing on materials selected from the initial list. Testing included longer-term tests with simulated feed preparation solutions and simulated off-gas condensate solutions.

Standard ASTM test methods (ASTM-G-1-81 and ASTM-G-31-72) were used or were adapted for use in the immersion testing, and ASTM-G-5-82 was used to guide potentiodynamic testing. Additional erosion/corrosion testing has been completed using procedures outlined in ASTM G-75-82 to determine Miller numbers (a relative index of abrasivity) for comparing the effects of handling different slurries on slurry-handling equipment.

Few constituents of the HWVP feed are expected to contribute significantly to corrosion of the candidate materials; these include chloride, fluoride, sulfate, nitrate, and formate in the acidic environments that are encountered. Certain transition metal ions contribute somewhat to corrosion but were not included in the early test solutions. Test durations were initially limited to a few days so as to evaluate several candidate materials rapidly. After the scoping tests, the reference feed and expected process conditions for HWVP were reevaluated. Appendix A lists the scoping test solutions and those used after reevaluation to test materials for the feed preparation and off-gas system equipment and gives the corrosion rates for the materials tested. During the scoping tests all but the titanium alloys exhibited uniform attack. Titanium Grade 7 alloy showed severe knife-line corrosion at the vapor-liquid interface, and titanium Beta-C showed very severe intergranular attack over the entire coupon. All results were statistically analyzed to determine a level of uncertainty for the calculated corrosion rates and to estimate the measurement variability. As a result of this work, the candidate alloys were ranked according to uniform corrosion rate as follows:

Higher Corrosion Rates Lower Corrosion Rates

(304-L, Ti alloys) (Carpenter $20 \mathrm{Cb}-3$ ) (Hast. G-3, ALLCORR) (Hast. C-276, C-22)

As a result of this testing, the candidate materials were divided into two groups based on relative corrosion resistance. Group 1 materials (the 
titanium alloys and 304-L stainless steel) had high corrosion rates and exhibited severe localized corrosion, and Group 2 materials (Carpenter $20 \mathrm{Cb}-3$, the Hastelloys, and ALLCORR) had relatively similar lower corrosion rates. Based on these results, the Group 1 materials were judged unsuitable for HWVP and dropped from further testing.

Follow-on testing conducted during 1987-1989 has included evaluations for uniform corrosion, crevice corrosion, stress corrosion, interfacial attack, and weld/heat-affected-zone attack through the use of appropriate coupon designs. Tabulated data for this testing, including corrosion rates obtained for the alloys tested, are found in Appendix A. Test results have demonstrated that Carpenter $20 \mathrm{Cb}-3$ is subject to various forms of localized corrosion in many solutions and conditions that may be found in the HWVP. Through 1989, no evidence of localized attack was evident in Hastelloy C-276 or $\mathrm{C}-22$ in PNL testing. Until testing to evaluate the proposed TRU recycle was initiated in 1989, Hastelloy C-276 remained the material of choice. Evidence of pitting, stress corrosion, and crevice corrosion may take very long times to appear, often requiring very long-term testing to confirm that they will occur in candidate materials.

In the proposed recycle, TRU-bearing process waste streams would be concentrated by boiling and then recycled back into the process. Under these conditions and applying the criteria of no localized corrosion (pitting, crevice corrosion, etc.) and <5 mpy uniform corrosion rate, Carpenter 20 Cb-3 was unacceptable and Hastelloy $\mathrm{C}-276$ was suitable if the simulated process waste was neutralized to $\mathrm{pH}-4$. Subsequent modifications to the TRU recycle process reduced the burden on the DWTT by treating the melter off-gas condensate to remove the TRU, cesium, and strontium by neutralization, ion exchange, and filtration followed by routing of the filtrate containing soluble anions, including halides, to the waste stream leaving the plant. The flexibility to handle these proposed recycle solutions while minimizing their neutralization requirements (introduction of sodium into the recycle) is needed in the HWVP design .

Long-term (up to -3 months) testing was conducted in 1989 to better correlate with in-service conditions and thus form a more reliable basis for 
materials selection. Testing was conducted to verify the performance of candidate materials exposed for relatively long times, in particular with cyclic replacement of solutions similar to those that will be seen in HWVP. The testing was designed also to identify impacts on materials of construction (particulariy the DWTT) resulting from the TRU recycle concept.

During FY 1989 testing, corrosion tests were conducted using $-50-\mathrm{h}$ cycles in boiling simulated feed slurry and simulated DWTT solutions. Unexpectedly high corrosion rates for the candidate materials in the original DWTT simulant, which simulated combining melter off-gas condensate with other process wastes, resulted in a revision of the solution composition. The revision was made to test a modified waste-handling process whereby the melter off-gas condensate would be treated separately from the other process wastes, el iminating the primary source of corrosive halides from the DWTT contents. The "other" process wastes would then be combined and concentrated in the DWTT by boiling. Two revised DWTT solutions were tested: one simulating unconcentrated waste and the other simulating the solution after a tenfold concentration by boiling. The compositions of the test solutions are shown in Table 5.5.

Approximate total exposure times for coupons in the various solutions were 1) $-2000 \mathrm{~h}$ in the feed slurry, 2) $-150 \mathrm{~h}$ in the original DWTT (including

TABLE 5.5. Compositions of FY 1989 HWVP Corrosion Test Solutions

\begin{tabular}{|c|c|c|c|c|}
\hline \multirow[b]{4}{*}{ Component } & \multicolumn{4}{|c|}{ Concentration, $\mathrm{ppm}$} \\
\hline & \multirow{3}{*}{$\begin{array}{l}\text { Feed Slurry } \\
\text { Simulant } \\
\end{array}$} & \multicolumn{3}{|c|}{ Process Waste Solution (DWTT) Simulants } \\
\hline & & & Revise & lutions \\
\hline & & Original & Unconcentrated & $10 x$ concentrated \\
\hline $\mathrm{F}^{-}$ & 1,250 & 3,000 & 100 & 1,000 \\
\hline $\mathrm{Cl}^{-}$ & 270 & 80,000 & 100 & 1,000 \\
\hline $\mathrm{SO}_{4}^{=}$ & 1,050 & 1,000 & -. & -- \\
\hline $\mathrm{NO}_{3}^{-}$ & 6,800 & 55,000 & 9,000 & 78,000 \\
\hline $\mathrm{Fe}^{3+}$ & & & 100 & 1,000 \\
\hline $\mathrm{Hg}$ & 100 & 100 & 100 & 1,000 \\
\hline $\mathrm{pH}$ & -3.5 & -3.0 & -1.0 & $<1.0$ \\
\hline
\end{tabular}


melter off-gas condensate) solution, 3) $\sim 1100 \mathrm{~h}$ in the revised "unconcentrated" DWTT solution, and 4) $-550 \mathrm{~h}$ in the revised "10X concentrated" solution. Corrosion rates in the simulated feed slurry averaged $<0.1$ mpy for the three candidate materials (Hastelloy C-276, Hastelloy C-22, and Carpenter $20 \mathrm{Cb}-3)$. In the original DWTT solution, the uniform corrosion rate for Hastelloy C-276 was 11.7 mpy, Hastelloy C-22 was 4.5 mpy, and Carpenter $20 \mathrm{cb}-3$ pitted so badly that no calculation was made for uniform corrosion. Uniform corrosion rates in the revised "unconcentrated" DWTT simulant were 1.4 mpy for the Hastelloy C-276, 0.2 mpy for the Hastelloy C-22, and 0.2 mpy for the Carpenter $20 \mathrm{Cb}-3$. No localized corrosion was observed in this test. In the test with the revised "10X concentrated" DWTT simulant, the uniform corrosion rates were 76.5 mpy for the Hastelloy C-276, 5.7 mpy for the Hastelloy C-22, and 12.7 mpy for the Carpenter $20 \mathrm{Cb}-3$.

Following the testing, the weld/stress coupons were examined visually for localized corrosion and were submitted for more detailed scanning electron microscopy (SEM) examination to determine whether specific components of the alloys were subject to preferential attack. Pitting was observed on some of the Carpenter $20 \mathrm{Cb}-3$ coupons from the lox concentrated solution test. No preferential dissolution was observed in any material by SEM analysis. Based on these results, acidic wastes of this type appear to be compatible with Hastelloy C-276 or Carpenter 20 Cb-3 only at dilute halide concentrations (total halides $<200 \mathrm{ppm}$, or maintain $\mathrm{pH}>3$ ). In more concentrated solutions, both Hastelloy $\mathrm{C}-276$ and Carpenter $20 \mathrm{Cb}-3$ are unacceptable. The performance of Hastelloy C-22 in the $10 \mathrm{X}$ solution exceeded only slightly the <5 mpy estab1 ished for HWVP. In the 10X solution the corrosion rate for Hastelloy C-22 was $5.7 \mathrm{mpy}$, and in all other solutions this alloy's corrosion rate has been 4.5 mpy or less and has shown no tendency for localized corrosion.

\subsection{LARGER SCALE TESTING}

Limited process testing for materials evaluation has been completed for DWPF with larger than laboratory-scale testing. This testing consisted of evaluation using varied sizes of process equipment in the feed preparation. areas and after melter tests. Integrated demonstration melter system (IDMS) 
testing is expected to continue for the DWPF during 1992. For the WVDP and HWVP, process testing is in the planning stages and evaluations are just beginning.

\subsubsection{Process-Scale Testing for DWPF}

Process-scale materials evaluations for DWPF have included investigations conducted during engineering-scale ceramic melter testing (ESCM) completed at PNL in 1982-83 and mini-melter testing and metal wear rate in sludge/frit slurries in a 1/3-scale SME/SRAT facility at SRL, and several full-scale SRAT/SME and scale glass melter (SGM) runs. IDMS testing at the SRL Engineering Test Facility (SRL-TNX) is being conducted for the DWPF using solutions containing mercury. The materials performance results from this testing will continue to be monitored by HWVP staff.

\subsubsection{Materials Evaluation After Melter Tests}

SRL reports that most alloys have proved unsatisfactory for use in melter vapor spaces (Bickford, Ondrejcin, and Sally 1987). Bickford, Ondrejcin, and Sally report also that alloys with high chromium content have shown the greatest resistance to molten glass. Inconel 690 containing $30 \%$ chromium is the preferred alloy al though "ductile chrome" is being considered for melter electrodes. Moreover, Inconel 690 is the only alloy that has proved generally reliable during melter testing in ESCM, mini-melter, or SGM testing. For example, Inconel 600,601 , and 690 were evaluated in melter vapor spaces and plenum chambers for 20 days at $-1800^{\circ} \mathrm{F}\left(1000^{\circ} \mathrm{C}\right)$. This testing was completed at PNL using the ESCM and simulated DWPF feed. Inconel 600 corroded halfway through over its entire surface, with local attack corroding through the entire thickness. When Inconel 601 was used for this same service, the outer reaction layer was $16 \mathrm{mils}$ deep and grain boundary penetration was $40 \mathrm{mils}$. Corrosion products for Inconel 600 were nickel sulfide, nickel oxide, iron oxide, and chromium sulfide, and for Inconel 601 they were chromium sulfide, chromium oxide, and nickel. Inconel 690 showed no evidence of sulfur attack. The reaction layer measured 2.4 mils thick, but it may originally have been thicker and may have spalled. Exposure times were too short to determine whether "breakaway" sulfidation occurred. During 2 years of operation of the large slurry-fed melter no evidence of sulfidation of 
Inconel 690 occurred. Some pitting of Inconel 690 thermowells has been noted in ESCM and mini-melter testing at SRL. In SGM testing at SRL, Monofrax K-3 ceramic and different alloys have been exposed to typical DWPF concentrations of organics, mercury, sulfates, and halides. Also evaluated were different refractory brick designs to minimize refractory spalling and fracture/dropout. There have been no changes in reference melter materials as a result of this work at SRS at this writing.

\subsubsection{Melter Off-Gas Line}

PNL performed pilot-scale testing for SRL in 1982-83. Critical operating conditions for further off-gas corrosion testing was based on the results of this pilot-scale testing. Since then, extensive melter testing for DWPF, HWVP, and WVDP and examination of construction materials such as 304-L stainless stee1, Carpenter $20 \mathrm{Cb}-3$, and Hastelloy $\mathrm{C}-276$ have shown that they would not be satisfactory in this service. Inconel 690 is typically attacked locally where temperatures remained above the dew point. Severe pitting was seen in portions of the DWPF off-gas quencher where the off gas reached its dew point. As a result, the quencher became an area of special study for DWPF. ALLCORR was tested for this application and resisted pitting, crevice corrosion, and other types of local attack. Ease of change-out was specified for the quencher, where attack is expected to be most severe. Since the HWVP off-gas system is based on the WVDP design, corrosion problems encountered with the DWPF quencher will be different or may not occur in the HWV system.

\subsubsection{Feed Preparation (SME/SRAT)}

Abrasive wear by DWPF slurries containing frit was first noted in 1981 at the SRL Engineering Test Facility. Pumps and process valves used in testing the melter slurry feed system at this time exhibited substantial abrasive wear on components. As a result, an effort was made to quantify erosion wear in frit slurries. In a 1/3-scale SRAT/SME, the corrosion/ abrasion of $304-\mathrm{L} \mathrm{flat}$ and pitched blades was on the order of $300 \mathrm{mils} / \mathrm{yr}$. No measurable wear was observed on tank walls (347-SS), baffles (304-SS), or coils (347-SS). Frit size ranged from -80 mesh to -200 mesh, agitator tip speed was 7 to $10 \mathrm{ft} / \mathrm{sec}$, and temperatures ranged from $-85^{\circ} \mathrm{F}\left(30^{\circ} \mathrm{C}\right)$ to $-215^{\circ} \mathrm{F}$ $\left(102^{\circ} \mathrm{C}\right)$. 
Additional testing was conducted for DHPF at the SRS Engineering Test Facility in 1982 using two 50-gal vessels with variable-speed agitators modified so that test specimens could be mounted on a rotating metal strut. Angular and spherical frit ranging from -20 to +325 mesh was tested at solids concentrations ranging from 40 to $55 \%$ and velocities from 3 to $30 \mathrm{ft} / \mathrm{sec}$. Wear rates appeared proportional to the velocity squared or cubed $\left(v^{2}\right.$ or $\left.v^{3}\right)$ and were much higher where angular frit was used. Additional evaluations of abrasion have been identified since this time in meetings between HWV and DWPF personnel using the 1/3-scale SRAT/SME and the full-scale SRAT/SME. Coupon testing both in the liquid, at the liquid-vapor interface, and in the vapor has been continued for the metals listed in Table 5.1 in these vessels, but a ranking of the alloys was not possible. As a result of wear in melter feed pumps, SRL is now using Stellite 6-B for impellers and pump liners and wet end components but not for dip legs. (a) Since then, no noticeable corrosion and only minor erosion have been observed. Weight loss for pump impellers after $-2000 \mathrm{~h}$ was reported to be $1.3 \%$. Agitator impeller erosion losses of up to $19 \mathrm{mils}$ over the same period were reported for SRAT/SME runs $\# 1,2$, and 3 , and average wear on the inner coils was 8.5 mils in 1215 SME hours of operation. The latter measurements were obtained by use of u7trasonics. Agitator impeller life was predicted at about 5 years, and coil life was predicted at 3 years. The approach used to attach coils to the coil supports is critical to ensuring maximum service life for the impellers.

\subsubsection{Process-Scale Testing for HWVP}

The pilot-scale ceramic melter (PSCM) was used from 1978 to 1985 in process-scale testing to evaluate materials for HWV construction. The melter was constructed of fused-cast chrome-alumina (Monofrax K-3) block and Inconel 690 in the areas contacting molten glass. It was inspected several times during operation, and materials performance has been evaluated. The melter walls, lid, electrodes, and pour trough corroded severely. Generally, electrodes constructed of Inconel 690 have performed well in a variety of melter environments, but for the PSCM corrosion was greater than expected. Inconel

(a) Telecon: April 9, 1990, M. R. Elmore and G. A. Jensen, PNL, 0. F. Bickford, SRS. 
690 exposed in plenum areas and the off-gas line was consistent with experience for other melters. The severity of corrosion of Inconel 690 in the PSCM was attributed to the halides and sulfates in the feed stream. The K-3 refractory performed consistent with the 5-year 1 ife of the melter. Where failures occurred (in the lid shell and refractory), design changes that used ceramic hangers instead of Inconel 690 solved the problem.

Process testing of the feed preparation (SRAT/SME) is scheduled to begin in 1991. Evaluation of materials performance, particularly related to slurry erosion, is to be a principal objective during that testing.

\subsection{MATERIALS TEST AND SELECTION SUMMARY}

This section summarizes materials testing for DWPF, WVDP, and HWVP that has been completed to specify materials for the slurry-processing, melter offgas and condensed vapor-recovery systems for HWVP. Materials testing for the melter and melter off-gas line were discussed earlier in sufficient detail so that no additional summary is needed.

Materials testing applicable to HWV has been completed for the DWPF, WVDP, and HWVP. Oniy materials of construction that showed promise in DWPF have been further tested for HWVP application. The primary materials included in the testing have been Hastelloy C-276 and Carpenter $20 \mathrm{Cb}-3$ for the feed preparation and off-gas systems. Hastelloy $\mathrm{C}-22$ was included in the 3-month testing because it is similar to Hastelloy $\mathrm{C}-276$ but is supposed to have better corrosion resistance in environments similar to the proposed TRU recycle.

All three of these candidate alloys have shown very low to minimal tendency for localized corrosion in PNL-HWVP and DWPF testing where the $\mathrm{pH}$ was 3.5 or above in the boiling solutions used. During PNL-HWVP testing and at WVDP, where the $\mathrm{pH}$ of the solutions was very low (pH -1 or less) and at or near boiling, pitting and other forms of localized attack was observed in Hastelloy C-276 but not in Hastelloy C-22. Carpenter $20 \mathrm{Cb}-3$ was not tested for the WVDP, but pitting has been observed in PNL-HWVP testing using DWTT simulants. 
In an attempt to correlate uniform corrosion rates for these three alloys, the averaged corrosion rates identified during the DWPF, WVDP and HWVP testing are plotted in Figures 5.1 through 5.5. Total halide, chloride, fluoride, nitrate, and mercury concentrations versus corrosion rates in mils per year are plotted in bar graphs. Tables $5.2,5.3$ and 5.5 provide the test solutions and are to be used with Figures 5.1 through 5.5. Attempts to plot the data in other formats produced nothing that could be interpreted reasonably. Even the bar graph data only show trends. Since Hastelloy C-22 and Carpenter $20 \mathrm{Cb}-3$ were not always included in the testing, the effect of pH and other components contained in the solutions cannot be defined clearly.

Overall, Hastelloy $\mathrm{C}-22$ shows the best performance for the slurryprocessing, melter off-gas and condensed vapor-recovery systems in the environments tested. Average corrosion rates for this alloy were usually $<4.5$ mpy and exceeded 5 mpy in only one test at very low pH in a high halidecontaining mercury environment. In this environment both Hastelloy C-276 and - Carpenter $20 \mathrm{Cb}-3$ exhibited extremely severe corrosion. A few test samples of Hastelloy C-22 in the WVDP testing showed minor evidence of localized surface attack. Halide concentrations as total halides (or as chloride or fluoride) appear to have minimal effect on the resulting corrosion rates for the different alloys. Where nitrate was below approximately $10,000 \mathrm{ppm}$, the corrosion rates for all three alloys were acceptable except where mercury was high. Mercury appears to increase the corrosion rate for Hastelloy C-276. The effect of the presence of mercury is not at all clear on the corrosion rate for Hastelloy C-22 or Carpenter $20 \mathrm{Cb}-3$. Hastelloy C-22 appears to tolerate the range of mercury concentrations expected for HWVP in the environments tested. In addition, the corrosion rate of 5.7 mpy was the maximum corrosion rate obtained for Hastelloy $\mathrm{C}-22$, and this was in a very low $\mathrm{pH}$, high halide environment where Hastelloy C-276 and Carpenter $20 \mathrm{Cb}-3$ essentially dissolved. Although this corrosion rate is marginal by the criterion established for HWVP, Hastelloy $\mathrm{C}-22$ should be the material of choice for the HWVP. In most other tests Hastelloy C-22 corrosion rates were well within the <5 mpy criterion established, while the other two alloys had either much higher annual 




FIGURE 5.1. Corrosion Rates Versus Halide Concentration for Construction Materials Considered for DWPF, WVDP, and HWVP. Test solutions are shown in Tables 5.2, 5.3, and 5.5, respectively.

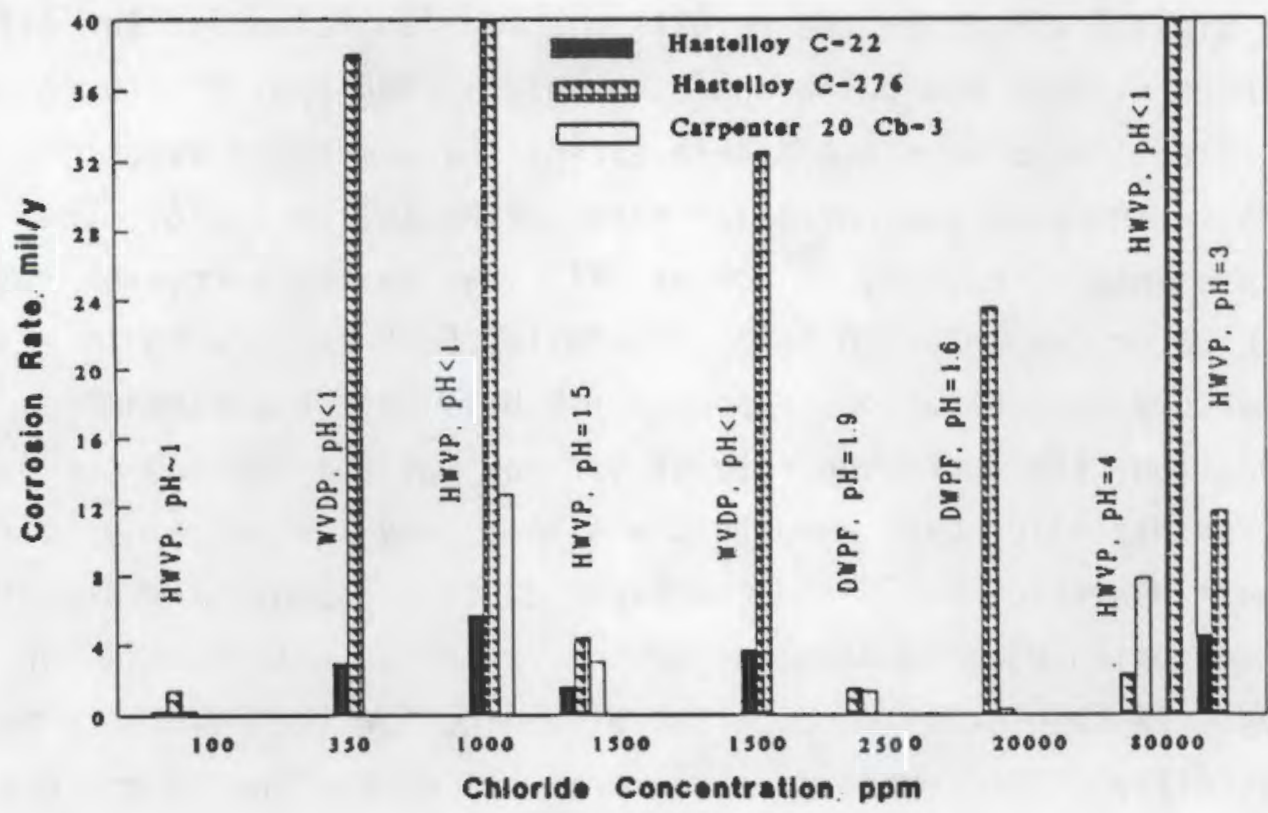

FIGURE 5.2. Corrosion Rates Versus Chloride Concentration for Construction Materials Considered for DWPF, WVDP, and HWVP. Test solutions are shown in Tables 5.2, 5.3, and 5.5, respectively. 




FIGURE 5.3. Corrosion Rates Versus Fluoride Concentration for Construction Materials Considered for DWPF, WVDP, and HWVP. Test solutions are shown in Tables 5.2, 5.3, and 5.5, respectively.

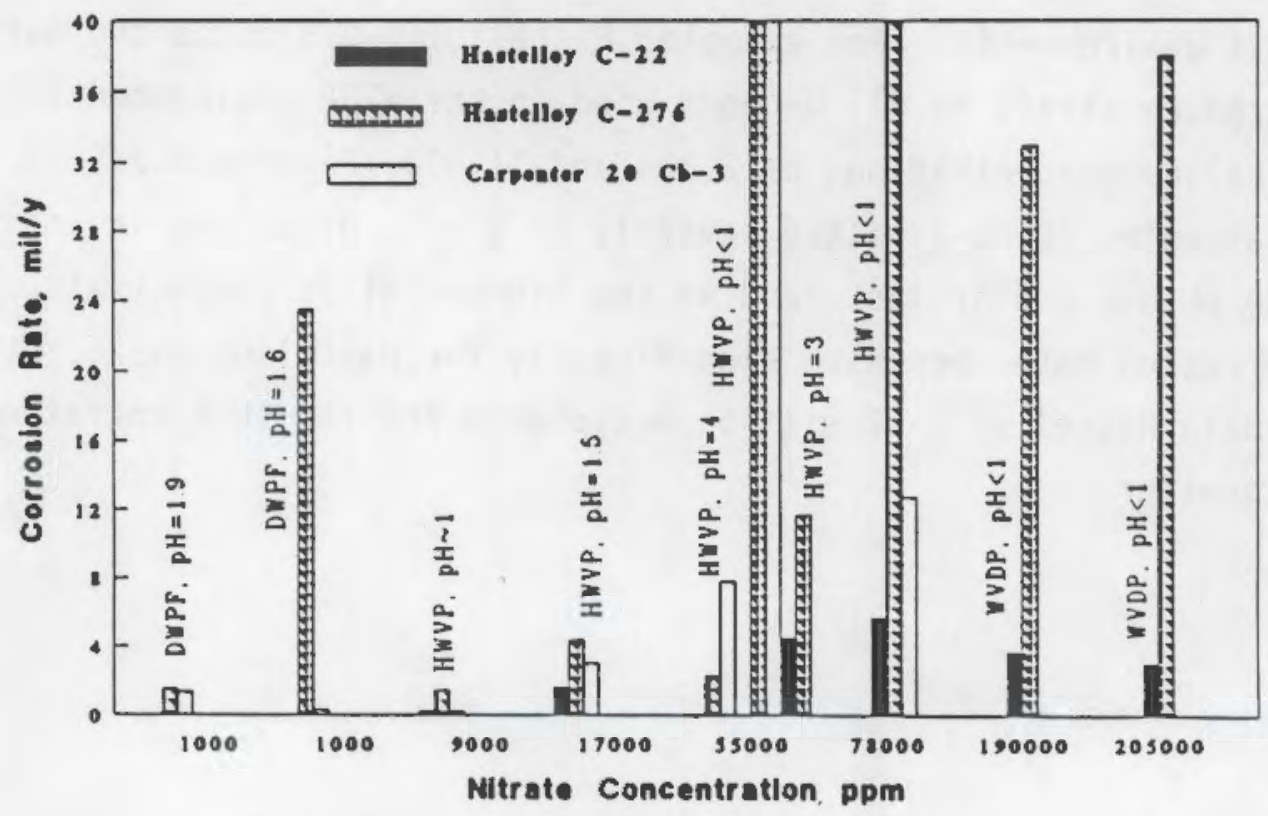

FIGURE 5.4. Corrosion Rates Versus Nitrate Concentration for Construction Materials Considered for DWPF, WVDP, and HWVP. Test solutions are shown in Tables 5.2, 5.3, and 5.5, respectively. 


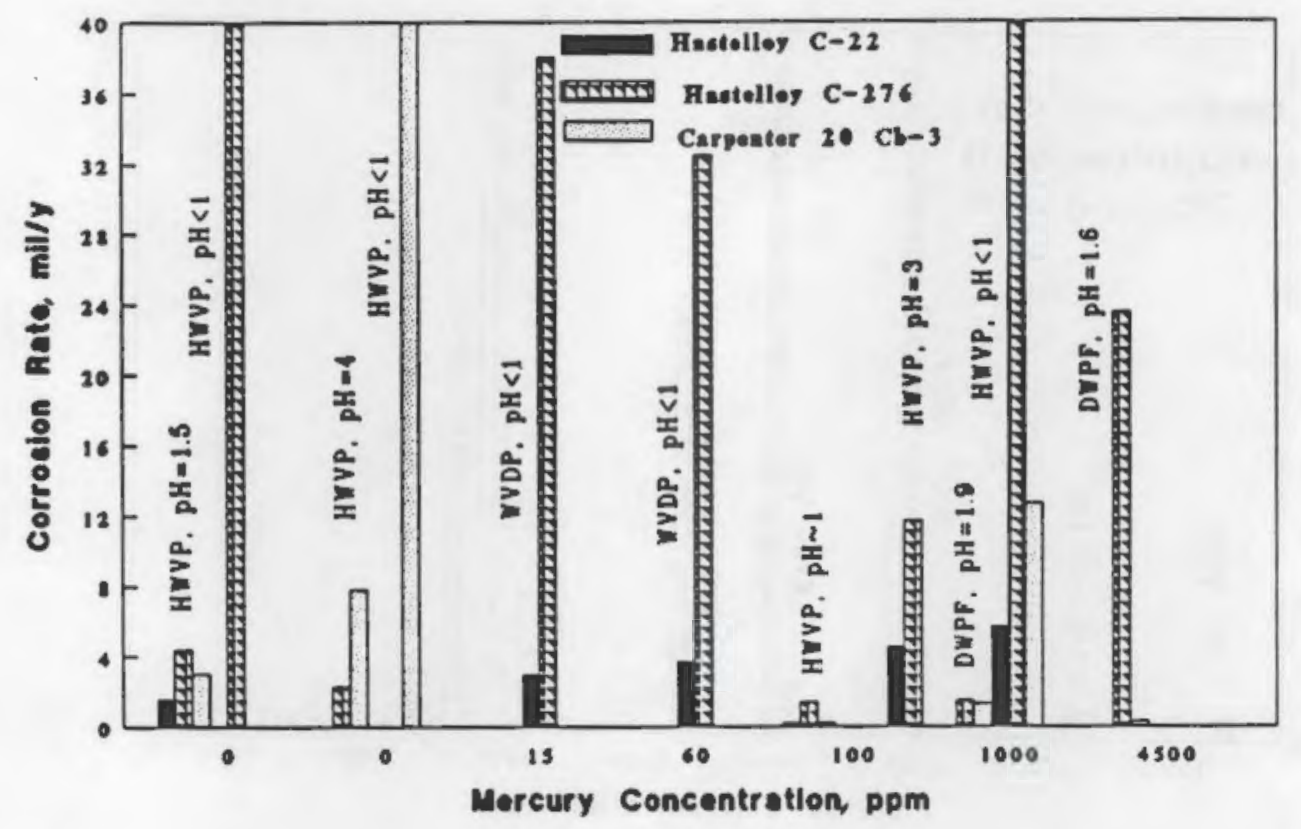

FIGURE 5.5. Corrosion Rates Versus Mercury Concentration for Construction Materials Considered for DWPF, WVDP, and HWVP. Test solutions are shown in Tables 5.2, 5.3, and 5.5, respectively.

corrosion rates or unacceptable localized corrosion not exhibited by Hastelloy C-22 in the test environments. For example, Hastelloy C-276 boits and nuts were used to produce stress in all U-bends used in the WVDP environments tested (total halide concentrations of 2,300 and 11,000, Figures 5.1-5.3) and all failed. Carpenter $20 \mathrm{Cb}-3$ pitted severely or simply dissolved in environments where the $\mathrm{pH}$ was 3.5 or less, and at the higher halide concentrations the uniform corrosion rate increased significantly for Hastelloy C-276. From the available data Hastelloy C-22 will be acceptable for the DWTT operating at a pH of -3 or greater. 


\subsection{MATERIALS SELECTION}

Using the criteria and guidelines developed in Section 4.1.1 and results of available materials performance information generated for DWPF, WVDP, HWVP, and others, reference materials are identified here for use in fabricating process equipment in the HWVP where reasonable confidence exists. These recommendations are found in Table 6.1; a discussion of their rationale is given in subsections organized by process area, i.e., embeds, slurry receipt and waste hold area, slurry processing and waste handling, melter, melter off-gas system, condensed vapor recovery, and other systems. More detail on these recomendations is found in Appendix B.

Although the Hastelloy alloys C-276 and C-22 are very similar in composition, the Hastelloy $\mathrm{C}-22$ in all testing proved more corrosion-resistant to a wider range of conditions than its predecessor, Hastelloy C-276. Hastelloy $\mathrm{C}-22$ is easier to fabricate than Hastelloy $\mathrm{C}-276$, has been developed to overcome the shortcomings of $\mathrm{C}-276$, and is available from suppliers. Discussions with representatives of both Haynes International (Hastelloy $C-22$ ) and INCO (INCO version of $\mathrm{C}-22$ is Inconel 622) indicate that the cost differential between $\mathrm{C}-276$ and $\mathrm{C}-22$ for fabricating equipment from either alloy will be essentially the same. Therefore, based on results of testing and on projected materials costs, Hastelloy $\mathrm{C}-22$ is recommended in general as the reference alloy for the slurry processing preparation, embedded piping, slurry receipt and waste hold, and melter off-gas systems. Discussions of materials recommendations for specific processing areas appear in the following sections.

\subsection{SLURRY TRANSPORT PIPING EMBEDOEO IN CONCRETE (EMBEDS)}

The recommended reference al loy for the slurry transport embedded piping is Hastelloy C-22. Significant reasons for this selection include the facts that 1) embedded piping is nonreplaceable and 2) there is no recovery from failure of embeds. Therefore, the best possible choice of alloy is recommended. This recommendation conforms to criterion 1 for $<5$ mpy corrosion rate and to Criterion 2 requiring the absence of localized corrosion. In laboratory testing for simulated HWVP solutions, pitting, crevice corrosion, and 


\section{TABLE 6.1. Materials Recommendations for Major Components of HWVP Chemical Process Equipment}

\begin{tabular}{|c|c|c|c|c|c|c|c|c|c|c|c|c|c|c|c|}
\hline \multirow[b]{3}{*}{ Component } & \multirow[b]{3}{*}{ RLST } & \multirow[b]{3}{*}{ HHT } & \multirow{2}{*}{\multicolumn{3}{|c|}{ Slurry Processing }} & \multicolumn{2}{|c|}{ Helter Area } & & & & \multicolumn{5}{|c|}{$\begin{array}{l}\text { Condensed Vapor } \\
\text { Recovery and Haste Handling }\end{array}$} \\
\hline & & & & & & off-Gas & & \multicolumn{3}{|c|}{ Melter off-Gas } & \multirow{2}{*}{\multicolumn{2}{|c|}{$\begin{array}{ll} & \text { PVV/ } \\
\text { SHECI } & \text { SBS } \\
\end{array}$}} & \multirow[b]{2}{*}{ DUTT } & \multirow[b]{2}{*}{$\underline{\text { RUCF }}$} & \multirow[b]{2}{*}{ WAT } \\
\hline & & & SRAI & SME & MEI & Line & Helter & $\underline{\mathrm{SBS}}$ & HEEFE & FFI & & & & & \\
\hline liessel & $c-22$ & $316 \mathrm{~L}^{(\mathrm{a})}$ & $c-22^{(b)}$ & $c-22$ & {$[-22$} & $1698^{(c)}$ & $K-3^{(d)}$ & $c-22$ & $c-22$ & $316 \mathrm{~L}$ & $316 \mathrm{~L}$ & $316 \mathrm{~L}$ & $c-22$ & $c-22$ & $316 \mathrm{~L}$ \\
\hline \multicolumn{16}{|l|}{ Transíer Pump } \\
\hline Casing & $c-22$ & $316 L$ & $C-22(e)$ & $c-22$ & $c-22$ & & & $c-22$ & $c-22$ & $316 \mathrm{~L}$ & $316 \mathrm{~L}$ & & $c-22$ & $c-22$ & $316 t$ \\
\hline Impe l ler & & $316 t$ & STLI & STLT & STLT & & & & & $316 \mathrm{~L}$ & $316 \mathrm{~L}$ & & $c-22$ & $c-22$ & $316 \mathrm{~L}$ \\
\hline Casing & $c-22^{(T)}$ & $316 \mathrm{~L}$ & $c-22$ & $c-22$ & $c-22$ & & & & & & $316 \mathrm{~L}$ & & C-22 & $c-22$ & $316 \mathrm{~L}$ \\
\hline Impeller & & $316 \mathrm{~L}$ & STLT & STLT & STLT & & & & & & $316 \mathrm{~L}$ & & C-22 & $c-22$ & $316 \mathrm{~L}$ \\
\hline Rgitator & $c-22$ & $316 \mathrm{~L}$ & $c-22$ & $c-22$ & $c-22$ & & & & & $c-22$ & & & c-22 & $c-22$ & $316 \mathrm{~L}$ \\
\hline Level Diptube & $c-22$ & $316 \mathrm{~L}$ & $c-22$ & $c-22$ & $c-22$ & & 1690 & $c-22$ & $c-22$ & $c-22$ & $316 \mathrm{~L}$ & 3162 & $c-22$ & $c-22$ & $316 \mathrm{~L}$ \\
\hline Thermowe 11 & $c-22$ & $316 \mathrm{~L}$ & $c-22$ & $c-22$ & $c-22$ & & J690 & $c-22$ & $c-22$ & & $316 \mathrm{~L}$ & $316 \mathrm{~L}$ & $C-22$ & $c-22$ & $316 \mathrm{~L}$ \\
\hline filter & & & & & & & & & & & & & & $c-22$ & \\
\hline
\end{tabular}

(a) 316L - 316L Stainiess Stee 1.

(b) C-22 - Hastelloy C-22.

(c) 1690 - Incone 1690 .

(d) K-3 - Monofrax K-3 refractory

(e) STLT - Stellite $6-B$.

(f) RLST - pumps and agitators are based on fluidics technologies. 
high corrosion rates have been seen on Carpenter $20 \mathrm{Cb}-3$ test coupons. Hastelloy C-276 has shown good resistance to pitting, crevice corrosion, and stress corrosion cracking in PNL or SRL testing to date, but uniform corrosion rates under TRU recycle and very low $\mathrm{pH}$ conditions have been higher than acceptable. Hastelloy $\mathrm{C}-22$ has shown superior performance compared to either Carpenter $20 \mathrm{Cb}-3$ or Hastelloy $\mathrm{C}-276$ in essentially all conditions tested.

\subsection{SLURRY RECEIPT AND LAG STORAGE}

The receipt and lag storage tanks (RLSTs) will receive caustic wastes from the 200 Area tank farms. The 200 Area caustic wastes will contain chlorides and fluorides at concentrations within the limits described by the HWVP feed specification. These components cause localized corrosion of typical stainless steels such as 304-L and 316-L at high temperature and/or low pH. A] so HWVP slurry or DWTT process liquids not meeting specifications for normal disposal may be rerouted to the RLST. These process streams may contain concentrations of chlorides and formates that can cause failure of stainless steel.

At one point, the preliminary design for HWVP isolated the RLSTs in a neariy inaccessible vault (as shown in Figure 4.2) next to the chemical process cell rather than in the canyon part of the plant where they could be serviced by the canyon crane (Option A). This Timitation made the RLSTs difficult to monitor and repair and almost nonreplaceable. Power fluidics technology for agitation and slurry pumping in the tanks, however, was expected to minimize the need for maintenance. The fluidics technology was expected to be very dependable and essentially maintenance-free, thereby minimizing the risk in not having access to the equipment from the canyon crane. A second option was considered locating the RLST as in Option A but making provisions for very limited access for inspection, maintenance, or replacement as a nonroutine activity requiring construction, if needed (Option $B$ ).

For Option A, because the RLSTs have increased risk of failure from corrosion if they are fabricated from stainless steel and their replacement will involve penetrating the vault at a large additional cost, Hastelloy $\mathrm{C}-22$ is recommended as the reference material of construction for these vessels and 
associated components. Hastelloy $\mathrm{C}-22$ is recommended also for the piping to and from the vessels that extends through the cell walls as nonreplaceabie embedded piping, regardless of the temperatures likely to be encountered during waste transfers (Asphahani and Manning 1987; Asphahani, Manning and Straachmann 1987). The recommendation of Hastelloy C-22 is also consistent with the DUPF materials choices, where Hastelloy $\mathrm{C}-276$ is specified for slurry transport lines from the upstream "low point" pump pits coming from the tank farm into the DWPF.

A possible alternative to Hastelloy $\mathrm{C}-22$ would be $316-\mathrm{L}$ stainless steel if RLSTs can be located where they are accessible (Option B). The use of 316-L stainless steel to construct the RLST's shel1 and internal components may be acceptable for the currently specified feed composition provided that the following design features are included: inspection ports; a continuous corrosion monitoring system; a viable method for decontamination, disposal, and replacement of the RLST system; and that verification testing of the stainless steel under simulated RLST operating conditions is available. If 316-L stainless steel is used, current best estimates available in the literature suggest the following limiting conditions: temperature less than $130^{\circ} \mathrm{F}$ and $\mathrm{pH}$ between 7 and 12 . Other factors, however, such as halide concentrations, etc., can increase the uncertainty regarding the material's resistance to pitting and other forms of localized corrosion (INCO CEB-2 1973; Uhl ig 1971).

\subsection{SLURRY PROCESSING}

The potential for corrosive conditions similar to those identified for slurry transport embeds exist throughout the feed preparation system.

Hastelloy $\mathrm{C}-22$ is recommended for a 11 equipment and piping components directly contacting feed slurries or derivative streams (i.e., condensate lines, etc.). Stellite 6-B is recommended for pump impellers and other equipment subjected to severe erosive conditions from high-velocity abrasive slurries. The risk of failure of auxiliary equipment and the cost of replacement (including downtime) for these tanks warrants recommending Hastelloy $\mathrm{C}-22$ as the reference material for the tanks and their auxiliaries. The abrasion resistance of 
Hastelloy $\mathrm{C}-22$ is expected to be very similar to that of Hastelloy C-276 because of their similar chemical compositions and physical properties. As such, Hastelloy C-22 does not present any special concerns regarding abrasion where Hastelloy $\mathrm{C}-276$ has proven acceptable.

\subsection{MELTER}

The melter is the other significant area in the HWV requiring special corrosion-resistant construction materials. Helter development has evolved over several years of testing at PNL, WVDP, and SRL. A generally accepted materials selection methodology for melter construction has been developed with this experience. For glass-contacting ceramics, Monofrax $\mathrm{K}-3$ is recommended. Many other ceramics have been previously tested in various glass compositions, but none appear sufficjently superior to Monofrax $\mathrm{K}-3$ while also providing the electrical resistance necessary for this application. Monofrax $E$ has shown corrosion resistance superior to that of $K-3$, due primarily to higher chromium content. But the electrical resistance of Monofrax $E$ is lower than that of $\mathrm{K}-3$, which is undesirable for joule-heated ceramic melter design. The Carborundum Corporation has recently introduced another refractory, Monofrax $Z$, which reportedly is superior to $X-3$ and may not suffer the electrical resistance problem of Monofrax E. Corrosion rates of K-3 in HWVP glass have not been established, but all test data using similar glasses show that K-3 would be acceptable for design basis. Further monitoring of materials performance, such as large-scale melter tests, must be continued. For example, the higher fluoride content of HWVP glass compared to OWPF glass could result in higher dissolution rates for the refractory exposed to molten glass (although perhaps negligibly so) if ail other conditions in the melter and glass are equal (temperature, convection velocity, redox state, and composition of all other glass constituents).

As a result of the same extensive background of testing for several vitrification processes, Inconel 690 is generally accepted as the alloy of choice for metallic components exposed to molten glass and high temperatures in the melter plenum (see Section 5.2). Other materials have been compared to Inconel 690 with mixed results. Again, as with the refractory corrosion 
rates, corrosion rates for Inconel 690 exposed in HWVP molten glass have not been determined, but performance of the alloy should be monitored in future melter testing. Another material, called "ductile chrome," is presently being evaluated by the Savannah River Site (SRS) as a promising substitute for Inconel 690 in DWPF glass-contacting applications (Bickford, Corbett, and Morrison 1986; Bickford and Corbett 1986). The material, its properties, and its limited melter testing have been oniy briefly described by SRS staff. The composition is proprietary at this time, but it is essentially a high-chrome alloy with trace additions of other components. Due to the refractory nature of pure chrome, the use of powder metallurgical techniques including hot isostatic pressing is required for fabrication. Only small test pieces for mini-melter electrodes have been fabricated to date for vitrification testing. Progress on this study is being tracked for HWVP interests. The development of new coatings for melter components is also being investigated, as described by the HWVP Applied Technology Plan.

\subsection{MELTER OFF-GAS SYSTEM}

Hastelloy $\mathrm{C}-22$ is recommended for fabrication of components of the offgas treatment equipment in contact with off-gas condensate. This application of Hastelloy C-22 is limited by high temperature on the inlet side of the melter off-gas system (for locations in the off-gas line where temperatures are above the dew point of the incoming off gas, Incone 1690 is recommended). Conditions observed in the high-efficiency mist eliminator (HEME) during the pilot-scale ceramic melter test PSCM-23, where $\mathrm{pH}-1$ halide-containing condensate was collected in the HEME drain, indicate that Hastelloy $\mathrm{C}-22$ should be used to at least this point in the off-gas train. Components not exposed to condensate solutions may be made from more standard materials which can be selected by the AE from published corrosion data.

\subsection{CONDENSED VAPOR RECOVERY AND WASTE HANDLING}

As mentioned in Section 5.1 , during laboratory tests with simulated DWTT solutions at very low $\mathrm{pH}(\sim 1$ or lower), very high uniform corrosion rates were evident on Carpenter $20 \mathrm{Cb}-3$ and Hastelloy C-276 test coupons. Subsequent 
testing in the same solution (but neutralized to $\mathrm{pH}-4$ ) resulted in much lower uniform corrosion rates for both alloys, 2.3 mpy for Hastelloy C-276 and 7.8 mpy for Carpenter $20 \mathrm{Cb}-3$. However, pitting and crevice corrosion were noted on some of the Carpenter $20 \mathrm{Cb}-3$ coupons. In subsequent long-term laboratory testing with similar solutions, corrosion rates for Hastelioy C-276 exceeded those for Carpenter $20 \mathrm{Cb}-3$ and Hastelloy C-22 for unneutralized DWTT solutions at boiling temperatures. Hastelloy $\mathrm{C}-22$ has performed well for most test environments simulating operation of the DUTT and is the recommended material for the DWTT and the RWCT. The contents of the DWTT must be maintained at $\mathrm{pH}>3$ since this vessel is to be used for concentration by boiling.

With proper pH control (>3) and temperature control (<130 $\mathrm{F}), 316-\mathrm{L}$ stainless steel is recommended for the WAT and WHT. Stainless steel is considered acceptable for these vessels and components because, unlike RLSTs, they are replaceable and conditions in them can be better controlled (INCO CEB-2, 1973; Uhitig 1971).

\subsection{OTHER SYSTEMS}

Other equipment not in direct contact with feed slurries or off-gas condensate streams, such as frit slurry feed lines, formic acid feed lines if maintained below $-120^{\circ} \mathrm{F}\left(-50^{\circ} \mathrm{C}\right)$ (INCO CEB-6 1979), electrical jumpers, etc., will not require fabrication from Hastelloy $\mathrm{C}-22$, with due consideration given for preventing galvanic corrosion between dissimilar metals. Materials for these other components can be selected from published data with reasonable confidence. For these systems, materials selection should be based on good engineering judgement and the application of the materials selection criteria established earlier and presented in this document, but should not require further verification testing. For example, the choice of 316-L stainiess steel for the SMECT, PFT, FSMT, etc., appears reasonable and within the criteria based upon the above strategy. 


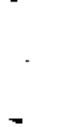




\subsection{ADDITIONAL MATERIALS CONSIDERATIONS}

Specific materials for specific applications for the plant process equipment have been recommended in preceding sections of this report. This section identifies additional monitoring of materials performance to complete materials selections and verify performance of HWV reference materials. The basis for this additional testing was presented in Section 3 under discussion of the approach to materials selections.

Because of the complex nature of these alloys, all aspects of the specification and fabrication process need to be carefully examined; otherwise the equipment produced may not perform as expected. Experience of DWPF staff has reinforced the authors' concerns regarding fabrication practices using the more exotic corrosion-resistant materials such as the Hastelloys. Specification documents prepared for vendors will require careful preparation and review to ensure that necessary construction practices for heat treatment/ stress relieving, weld specifications, flaw repair in castings, etc., are carefully followed and that unacceptable practices are not used.

Fabricators may have 1 imited and inadequate knowledge when dealing with the specialized equipment designs needed for HWVP, and careful monitoring of their activities by personnel knowledgeable in the special alloys, e.g., Hastelloy $\mathrm{C}-22$, is needed. A knowledgeable team should be assembled to review and monitor HWVP equipment designs to determine that acceptable practices are followed for fabrication with these types of materials. The project should also consider developing a catalog of approved construction practices to reference on drawings and other design media. The vendors of these materials should be included in the development of these approved construction practices.

In addition, specific project requirements should be developed outlining a quality control program to inspect, test, and control materials and spare parts to avoid alloy mix-ups. The degree of testing to be done for materials acceptance might range from spot checks to corrosion acceptance testing of all lots of construction materials for remote process equipment as was done for DWPF. The cost versus benefit of such testing must be assessed. 


\subsection{REFERENCES}

Agarwa1, D. C., F. G. Hodge, and 1. J. Storey. 1985. "Combatting Dewpoint Corrosion with High-Performance $\mathrm{Ni}-\mathrm{Cr}$-Mo-type Alloys." In Dewpoint Corrosion, Ellis Norwood Limited, Chichester, England.

American National Standards Institute and American Society of Mechanical Engineers (ANSI/ASME) B31.1-1989, B31.3-1990 "American National Standard Code for Pressure Piping - Power Piping, Chemical Plant and Petroleum Refinery Piping: Chapter III Materials."

American Society for Testing and Materials (ASTM). 1988. Annual Book of Standards. Philadelphia, Pennsylvania.

Asphahani, A. I., and P. E. Manning. 1987. Hastelloy Alloy C-22 A Most Versatile Corrosion-Resistant Nickel-Base Alloy. Haynes International, Inc., Technical Information Bulletin $\mathrm{H}-2047$.

Asphahani, A. I., P. E. Manning, and J. E. Straachmann. 1987. "New Advances in Molybdenum-Containing Corrosion-Resistant Alloys." Molybdenum Mosaic $10(1): 1-5$.

Baxter R. G. 1983. Description of Defense Waste Processing Facility Reference Waste Form and Canister.. DP-1606, Rev. 1, E. I. du Pont de Nemours \& Company, Savannah River Plant, Aiken, South Carolina.

Bickford, D. F., and R. A. Corbett. 1984. "Material Selection for the Defense Waste Processing Facility." In Conference Proceedings on the International Conference of Corrosion of Nickel-Base Alloys, American Society for Metals, Metals Park, Ohio.

Bickford, D. F., R. A. Corbett, and W. S. Morrison. 1985. "Test Methods for Selection of Materials of Construction for High-Level Radioactive Waste Vitrification." DP-MS-85-151, Rev., E. I. du Pont de Nemours and Company, Engineering Department, Wilmington, Delaware, and Savannah River Laboratory, Aiken, South Carolina.

Bickford, D. F., R. A. Corbett, and W. S. Morrison. 1986. "Corrosion Evaluation of Alloys for Nuclear Waste Processing." DP-MS-85-151, E. I. du Pont de Nemours and Company, Engineering Department, Wilmington, Delaware, and Savannah River Laboratory, Aiken, South Carolina.

Bickford, D. F., R. B. Diemen, Jr., and D. C. Iverson. 1986. "Redox Control of Electric Melters with Complex Feed Composition." Journal of NonCrystalline Solids, 84:285-91, North Holland, Amsterdam.

Bickford, D. F., and R. A. Morrison. 1986. "Material Selection for Nuclear Waste Processing Facility." J. Materials for Energy Systems 8(2):142-149. American Society for Metals, Metals Park, Ohio. 
Bickford, D. F., R. S. Ondrejcin, and L. Sally. 1987. "High-Temperature Materials for Radioactive Waste Incineration and Vitrification," in Nuclear Waste Management: Advances in Ceramics, Vol. 20, pp. 65-78. American Ceramic Society, Westerville, Ohio.

Corbett, R. A., D. F. Bickford, and W. S. Morrison. 1986. "Corrosion Evaluation of Alloys for Nuclear Waste Processing." Proceedings of the Iechnical Symposium of Corrosion 86. National Association of Corrosion Engineers, Houston, Texas.

Dene, C. 1985. "Corrosion and Erosion of Outlet Ducts." ECS UPDATE, Winter 1985-86, No. 3. Environmental Control Systems Department, Electric Power Research Institute, Palo Alto, California.

DOE Order 6430.1A. Apri1 6, 1989. General Design Criteria for Department of Energy Facilities.

DOE Order 5820.2A. September 26, 1988. Radjoact ive Waste Managenent.

DOE Order 5400.1. November 11, 1988. General Environmental Protection Program.

Farnsworth, R. K., C. M. Ruecker, J. M. Perez, Jr., H. T. Blair, and G. T. Thornton. 1986. Feed Process Variability Testing for Fiscal Year 1986. RHO-RE-CR-16P/HWV-V1123C, Pacific Northwest Laboratory, Richland Washington.

Fontana, M. G., and N. D. Greene, 1978. Corrosion Engineering. McGrawHill, New York.

HWV Design Unit Staff, 1990. Functional Design Criteria Hanford Waste Vitrification Plant: Project 595. WHC-SD-HWV-FDC-0001, Westinghouse Hanford Company, Richland, Washington.

HWVP Staff. 1987. Hanford Waste Vitrification Plant Reference Conceptual Design Report. WHC-EP-D04, Westinghouse Hanford Co., Richland, Washington.

HWVP Staff. 1989. Hanford Waste Vitrification Plant Technical Data Package. WHC-SD-DP-0001, Westinghouse Hanford Company, Richland, Washington.

INCO. 1963. Corrosion Resistance of the Austenitic Chromium-Nickel Stainless Steels in Chemical Environments. International Nickel Company, 1 New York Plaza, New York.

INCO CEB-2. 1973. Corrosion Resistance of Nickel and Nickel-Containing Alloys in Caustic Soda and Other Alkalies. International Nickel Company, 1 New York Plaza, New York.

INCO CEB-6. 1979. Corrosion Resistance of Nickel Containing Alloys in Organic Acids and Related Compounds. International Nickel Company, I New York Plaza, New York. 
Perrigo, L. D., and G. A. Jensen. 1983. "Fundamentals of Corrosion Control Design." BNWL-SA-5289, Rev., 13th Western States Corrosion Seminar, Pomona, California.

Perry, J. H., ed. 1984. Chenical Engineers Handbook, 6th_Ed.. McGraw-Hill Book Company, New York.

Ryder, D. E. 1989. Quality Assurance Manual. PNL-7000, Pacific Northwest Laboratory, Richland, Washington.

Uhlig, H. H. 1971. Corrosion and Corrosion Control. John Wiley and Sons, Inc., New York.

Vyas, Brijesh. 1979. "Erosion Corrosion." Treatise on Materials Science and Technology, Vol. 16, pp. 357-395. 
$-$ 


\section{APPENDIX A}

DETAILS OF HWVP MATERIALS TESTING 
APPENDIX A

\section{DETAILS OF HWVP MATERIALS TESTING}

Original reference materials of construction for the HWVP were based on materials selected for the DWPF, much like other aspects of the plant design. The basis for this approach was that both facilities would be processing similar feed materials in similar flowsheets. However, known differences in the feed compositions and flowsheets were recognized that could have an unknown impact on materials performance.

In FY 1986 PNL conducted a preliminary materials selection review for HWVP. Expected waste stream compositions and process conditions were reviewed, and DWPF materials selection studies were evaluated for applicability to HWVP materials requirements. Based on available information regarding HWVP feed composition and processing conditions, a preliminary reference materials list was proposed for aqueous-service remote process equipment, and recommended materials testing was outlined. Preliminary scouting tests with these materials were performed in a succeeding study. As a result of those tests, subsequent tests focused on two alloys for slurry processing and off-gas treatment, Carpenter $20 \mathrm{Cb}-3$ and Hastelloy C-276. In FY 1988 a study was conducted to determine the anticipated cost differential between these two materials for HWVP equipment fabrication. Based on available information, the difference in life-cycle costs for the two materials is anticipated to be small.

A reference feed slurry composition for HWVP was specified in FY 1988 (Watrous and Kruger 1987). Questions remained, however, concerning feed slurry characterization and the accuracy of present simulations. Testing was also conducted in FY 1988 to assess the impact of TRU-bearing process waste stream recycle on materials requirements for feed preparation and process waste handling equipment. Results indicated that neither Carpenter $20 \mathrm{Cb}-3$ or Hastelloy $\mathrm{C}-276$ would be compatible with a process based on boiling untreated off-gas condensate in an evaporator to concentrate the TRU-bearing solution 
for recycle back into the process. Only the C-276 was compatible with a boiling neutralized $(\mathrm{pH}-4)$ condensate; coupons of the Carpenter $20 \mathrm{Cb}-3$ exhibited pitting and crevice corrosion.

In FY 1989 long-term, small-scale laboratory tests were conducted to further evaluate Hastelloy $\mathrm{C}-276$ and Carpenter $20 \mathrm{Cb}-3$ as the present reference materials, and obtain preliminary corrosion rates for design for HWVP process equipment materials of construction, specifically the governmentfurnished equipment and piping associated with feed preparation, off-gas condensate treatment, and process waste handling. The scope of FY 1989 testing included -4 -month and longer tests of the materials under cyclic process conditions.

After the preliminary results showed severe corrosion of the test coupons, and in conjunction with updated TRU-recycle process flowsheet calculations, a revised OWTT solution was proposed for follow-on testing. The new solution simulated a waste solution consisting of SMECT condensate, decontamination wastes, and other sump and drain wastes. Two tests were conducted with this composition: one using the initial unconcentrated composition, and the other as if the DWTT were concentrated by boiling to 10 times the initial concentration.

Preliminary results of the tests in the concentrated solution showed the Hastelloy $\mathrm{C}-276$ corroded at a faster rate than the Carpenter $20 \mathrm{Cb}-3$ (-40 to 60 mpy versus -10 mpy), while the Hastelloy $\mathrm{C}-22$ performed well (-1 to 5 mpy). Because the $10 x$ concentration solution is a nitric acid solution with other contaminants, it is possible that the explanation for the results is the chromium content of the alloys. Both the Carpenter $20 \mathrm{Cb}-3$ and the Hastelloy $\mathrm{C}-22$ have chromium contents of $\sim 20 \mathrm{wt} \%$ while the $\mathrm{C}-276$ chromium content is less, $-18 w t \%$. According to technical brochures and from conversations with vendor representatives, the higher chromium increases the aljoys' resistance to oxidizing conditions such as the nitric acid solutions. More detailed analysis and evaluation of the coupons was performed and was reported in a summary report in Fy 1990.

Long-term (-2 to 3 months) laboratory corrosion tests were conducted to verify performance of candidate materials that have previously been evaluated 
in simulated HWVP process solutions. Solutions included a simulated feed slurry, and simulated process waste recycle solutions. Mercury, recently identified in NCAW tank samples, was added to the test solutions. Tests were conducted at boiling, and test solutions were regularly replaced at $50-\mathrm{h}$ intervals.

Two classes of alloys were evaluated in the long-term tests: Carpenter $20 \mathrm{Cb}-3$, a high alloy "stainless steel," and Haynes Hastelloys C-276 and $\mathrm{C}-22$, premium $\mathrm{Ni} / \mathrm{Cr}$ alloys for generally severe aqueous corrosion environments. Hastelloy $\mathrm{C}-22$ was included along with the other two alloys to further investigate positive results of some earlier short-term tests with that alloy.

Preliminary results of the feed siurry tests showed no significant differences in corrosion of any of the three alloys. Mercury-related localized corrosion was noted by DWPF tests with Carpenter $20 \mathrm{Cb}-3$, but was not evident with the Hastelloy alloys. However, in long-term HWVP feed slurry tests with mercury concentrations of $-100 \mathrm{ppm}$, no localized corrosion was seen on any of the coupons. Later results of longer term testing, however, showed Hastelloy $\mathrm{C}-22$ to be more corrosion-resistant than the other two materials.

Significant corrosion was noted with both the Carpenter $20 \mathrm{Cb}-3$ and the Hastelloy C-276 in the simulated process waste solutions. Initially, a solution composition based on a total recycle of process wastes through the OWTT was evaluated for compatibility with the test alloys. Severe corrosion rates were seen after only about 6 days of exposure. Pitting and crevice corrosion, as well as high rates of uniform corrosion were noted.

Tables A.l through A.7 provide further details of HWVP testing of materials. 
TABLE A.1. Compositions of Solutions Used for Corrosion Testing

HWVP Test Solution Compositions

\begin{tabular}{|c|c|c|c|}
\hline Component & $\begin{array}{l}\text { Scoping }(a) \\
\text { Tests, } \\
\text { ppm } \\
\end{array}$ & $\begin{array}{c}\text { Feed }(b) \\
\text { Preparation, } \\
\text { ppm }\end{array}$ & $\begin{array}{c}\text { Off-Gas (c) } \\
\text { Condensate, } \\
\text { opm } \\
\end{array}$ \\
\hline $\mathrm{Cl}^{+}$ & 1,000 & 1,000 & 1,500 \\
\hline$F^{*}$ & 5,000 & 5,000 & 7,000 \\
\hline $\mathrm{SO}_{4}=$ & 10,000 & 5,000 & 7,000 \\
\hline $\mathrm{NO3}^{-}$ & 1,000 & 12,000 & 17,000 \\
\hline $\mathrm{COOH}^{-}$ & 10,000 & 16,000 & 0 \\
\hline
\end{tabular}

(a) Solution $\mathrm{pH}-2$.

(b) Solution $\mathrm{pH}-2,-4$.

(c) Solution $\mathrm{pH}-1, \sim 2$.

IABLE A.2. Corrosion Rates for Preliminary Scoping Tests (a)

Material
304L SS
Ti Beta-C(b)
Ti Gr-7 (b)
Carpenter 20 Cb-3
Haste1loy C-276
Hastelloy C-22
Hastelloy G-3
ALLCORR

Corrosion Rates, mils per year

(a) Solution temperature $225^{\circ} \mathrm{F}\left(-102^{\circ} \mathrm{C}\right)$; solution $\mathrm{pH}-2$. Corrosion rates given are averages of duplicate coupons for each test except as otherwise indicated.

(b) Duplicate tests were not performed. 
IABLE A.3. Corrosion Rates for Simulated (a) Welded Coupons ${ }^{(b)}$

Material
Carpenter $20 \mathrm{Cb}-3$
Hastelloy $\mathrm{C}-276$
Hastelloy $\mathrm{C}-22$

\begin{tabular}{ccccc}
\multicolumn{4}{c}{ Corrosion Rates, mils per year } \\
\cline { 2 - 2 } Condensate & Vapor Space & Interface & Submerged \\
\cline { 3 - 5 } 1.0 & 1.2 & 26.2 & 31.9 \\
0.0 & 0.1 & 4.6 & 3.9 \\
0.0 & 0.1 & 3.3 & 2.9
\end{tabular}

(a) Simulated welds were created by a gas tungsten arc drawn across the surface of the coupons to produce a molten region and a heat-affected zone.

(b) Solution temperature $-215^{\circ} \mathrm{F}\left(\sim 102^{\circ} \mathrm{C}\right)$; solution $\mathrm{pH} \sim 2$. Corrosion rates are for single coupon tests, not duplicates. TABLE A.4. Corrosion (Rates for Coupons in Simulated Feed Preparation

Material
Carpenter 20 Cb-3
Hastelloy C-276
Hastelloy C-22
ALLCORR

Corrosion Rates, $\frac{\text { mils per year }}{\mathrm{pH}-2}$

$48.0 \quad 85.0$

$68.2 \quad 12.2$

$15.1 \quad 12.2$

$8.6 \quad 4.7$

(a) Corrosion rates are averages of duplicate coupons for each test. Temperature of solution was boiling $\left(-102^{\circ} \mathrm{C} / 215^{\circ} \mathrm{F}\right)$. 
IABLE A.5. Corrosion Rates for Coupons in Simulated Feed Slurries(a)

\begin{tabular}{l} 
Materia] \\
\hline Carpenter $20 \mathrm{Cb}-3$ \\
Hastelloy $\mathrm{C}-276$ \\
Hastelloy C-22 \\
ALLCORR
\end{tabular}

Corrosion Rates, mils per year

\begin{tabular}{|c|c|}
\hline Unformated (b) & Forma \\
\hline $\begin{array}{l}0^{(c)} \\
0 \\
0 \\
0\end{array}$ & $\begin{array}{l}0 \\
0.1 \\
0 \\
0\end{array}$ \\
\hline
\end{tabular}
(a) Corrosion rates are for single coupon tests, not duplicates. Temperature of solution was boiling $\left(-102^{\circ} \mathrm{C} /-215^{\circ} \mathrm{F}\right)$.
(b) Unformated refers to slurries prior to reaction with formic acid; formated is after acid addition.
(c) Zero values were essentially at or below detection, assumed less than 0.1 mpy.

TABLE A.6. Corrosion (Rates for Coupons in Simulated Off-Gas Condensate Solutions $(a)$

\begin{tabular}{l} 
Material \\
\hline Carpenter $20 \mathrm{Cb}-3$ \\
Hastelloy $\mathrm{C}-276$ \\
Hastell loy $\mathrm{C}-22$ \\
ALLCORR
\end{tabular}

(a) Corrosion rates are averages of duplicate coupons for each test. Temperature of solution was boiling $\left(-102^{\circ} \mathrm{C} /-215^{\circ} \mathrm{F}\right)$.

\begin{tabular}{|c|c|}
\hline $\mathrm{pH}-2$ & $\mathrm{pH}-4$ \\
\hline $\begin{array}{l}2.7 \\
3.5 \\
1.3 \\
1.5\end{array}$ & $\begin{array}{l}3.4 \\
5.2 \\
1.8 \\
1.8\end{array}$ \\
\hline
\end{tabular}




\begin{tabular}{|c|c|c|}
\hline \multirow[b]{2}{*}{ Material } & \multicolumn{2}{|c|}{$\begin{array}{l}\text { Corrosion Rates, } \\
\text { mils per year }\end{array}$} \\
\hline & Unformated $(\mathrm{a})$ & Formated $(\mathrm{b})$ \\
\hline $\begin{array}{l}\text { Carpenter } 20 \mathrm{Cb}-3 \\
\text { Hastelloy } \mathrm{C}-276 \\
\text { Stellite-6 }\end{array}$ & $\begin{array}{r}2100 \\
1400 \\
100\end{array}$ & $\begin{array}{r}700 \\
500 \\
30\end{array}$ \\
\hline
\end{tabular}

(a) Slurry A - frit/formic acid/water.

(b) Slurry B - Simulated HWVP feed/frit/formic acid/water. Slurry was at room temperature $\left(-25^{\circ} \mathrm{C} /-77^{\circ} \mathrm{F}\right)$.

\section{REFERENCE}

Watrous, R. A., and 0. L. Kruger. 1987. HWVP Heat Specification: Pretreated Neutralized Current Acid Waste. SD-HWVP-OCD-001 Rev.1, Westinghouse Hanford Company, Richland, Washington. 
. 


\section{APPENDIX B}

MATERIALS SELECTION GUIDES FOR SELECTED HWVP

REMOTE PROCESS VESSELS AND EQUIPMENT 


\section{MATERIALS SELECTION GUIDES FOR SELECTED HWVP REMOTE PROCESS VESSELS AND EQUIPMENT}

The following sketches graphically present the results and recommendations of this study (recommended construction materials for remote process equipment systems and major components in the HWVP). They provide additional detail in materials recommendations for specific process equipment components that supplements the information in the text and tables of the main report. The basis for those recommendations is to be found in the discussion and references cited in the report. The figures in this appendix include the principal process vessels and associated equipment and piping as follows:
B.2 Receipt and Lag Storage Tank (RLST)
B.3 Slurry and Receipt Adjustment Tank (SRAT)
B.4 Slurry Mix Evaporator (SME)
B.5 Slurry Mix Evaporator Condensate Tank (SMECT)
B.6 Melter Feed Tank (MFT)
B.7 Decontamination Waste Treatment Tank (DWTT)
B.8 Melter Off-Gas Submerged Bed Scrubber (SBS)
B.9 Filter Feed Tank (FFT)
B.10 Recycle Waste Collection Tank (RWCT)
B.11 Waste Adjustment Tank (WAT)

These recommendations are based on available information and the preliminary design status of HWVP. In the detailed design process, additional considerations or engineering trade-off studies could affect the final choice and specification of materials for HWVP construction. 


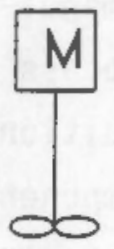

AGITATOR

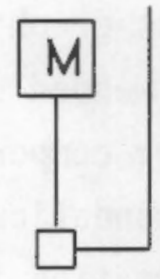

PUMP

HEATING/COOLING COIL

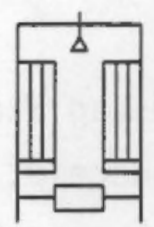

CONDENSER

FIGURE B.1. Key to Components in the Following Diagrams 


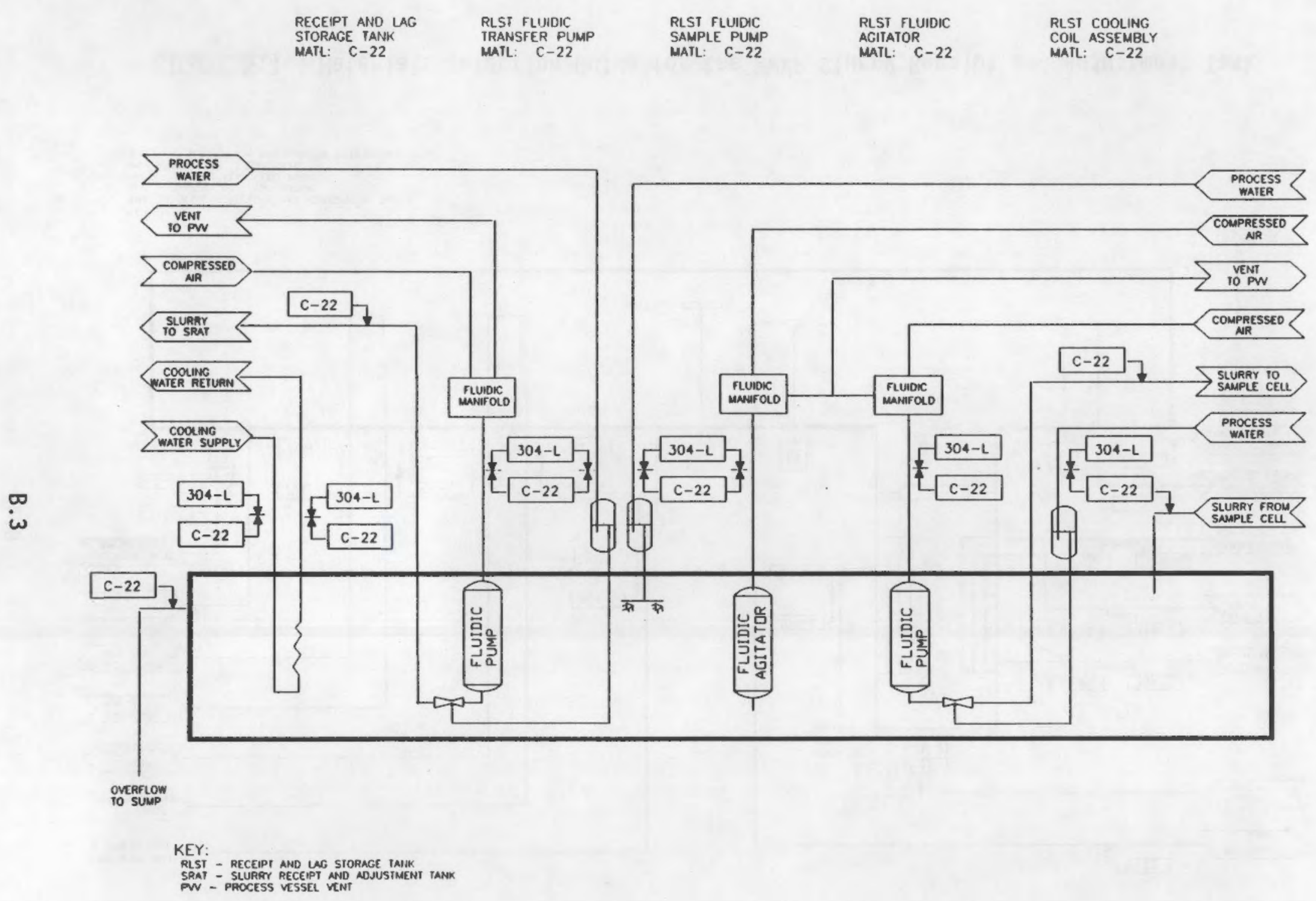

FIGURE B.2. Materials Selection Guide for the HWVP Receipt and Lag Storage Tank 
SLURRY RECEIPI AND ADJUSTMENT TANK

SRAT SAMPLE PUMP

MATL: $C-22$

STELLITE 68 (WET ENO)

304-L (NON-WETTEO)
SRAI TRANSFER PUMP

MATL: $\mathrm{C}-22$

STELLITE 6 (WET ENO) 304-L (NON-WETEO)
SRAT AGITATOR

MATL: $\mathrm{C}-22$

304-L (NON-WETTEO)
SRAT HEATING/COOLING COIL ASSEMELY MATL: C-22
SRAT CONDENSER MAIL: $\mathrm{C}-22$

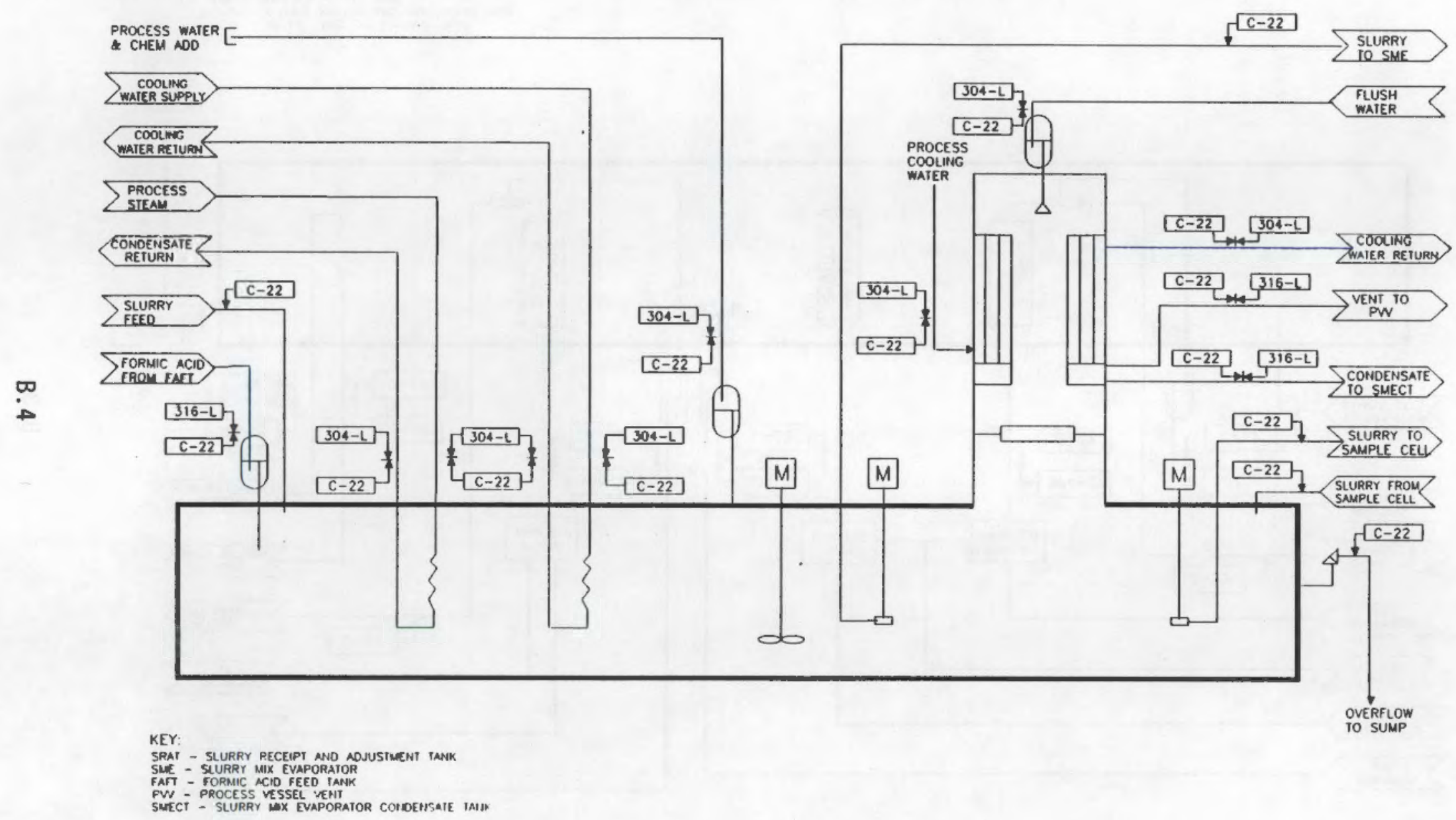

FIGURE B.3. Materials Selection Guide for the HWVP Slurry Receipt and Adjustment Tank 
SME VESSEL SME SAMPLE PUMP

HATL: $\mathrm{C}-22$

MATL: C-22

STELLITE 6B (WET END)
304-L (NON-WETED)
SME IRANSFER PUMP

MAIL: C-22 STELLITE $6 B$ (WET END)
SME AGITATOR

MATL: C-22

304-L (NON-WETTED)
SME HEATING/COOL.ING

COHL ASSEMBLY

MATL: C-22
SME CONDENSER MAIL: C-22

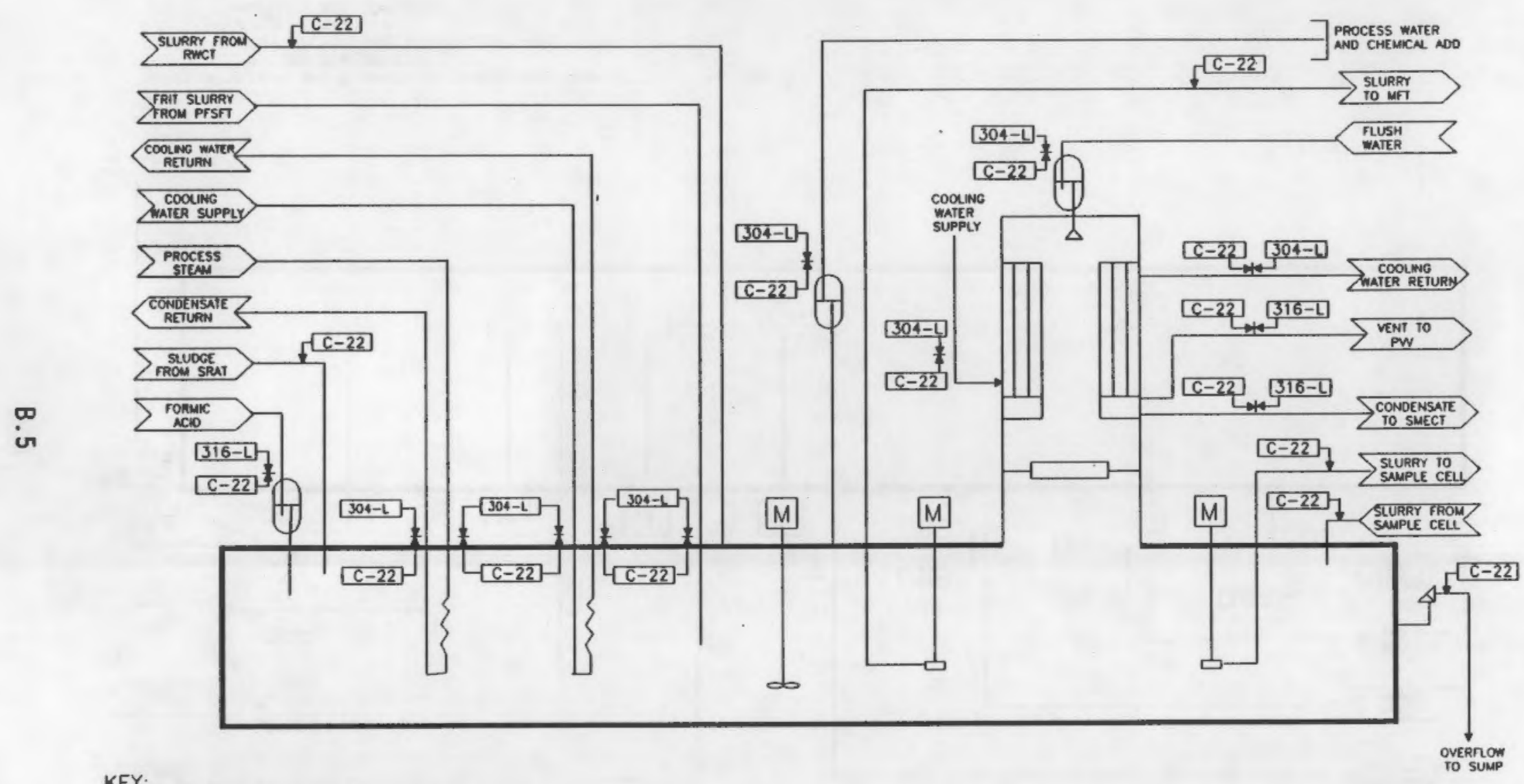

SME - SLURRY MIX EVNPORATOR
PFSFT - PROCESS FRIT SLURRY FEED TANK

SRAT - SLURRY RECEIPT AND ADJUSTMENT TANI

MNIT - MECYCLE WASTE COLE

SMECT - RLURRY MIX EVAPORAIOR CONDENSATE TANK

FIGURE B.4. Materials Selection Guide for the HWVP Slurry Mix Evaporator Equipment 
SLURRY MIX EVAPORATOR

CONDENSAIE TANK

MAIL: $316-L$
SMECT SAMPLE PUMP

MAII: $316-L$
SMECT TRANSFER PUMP MAIL: $316 \cdots 1$

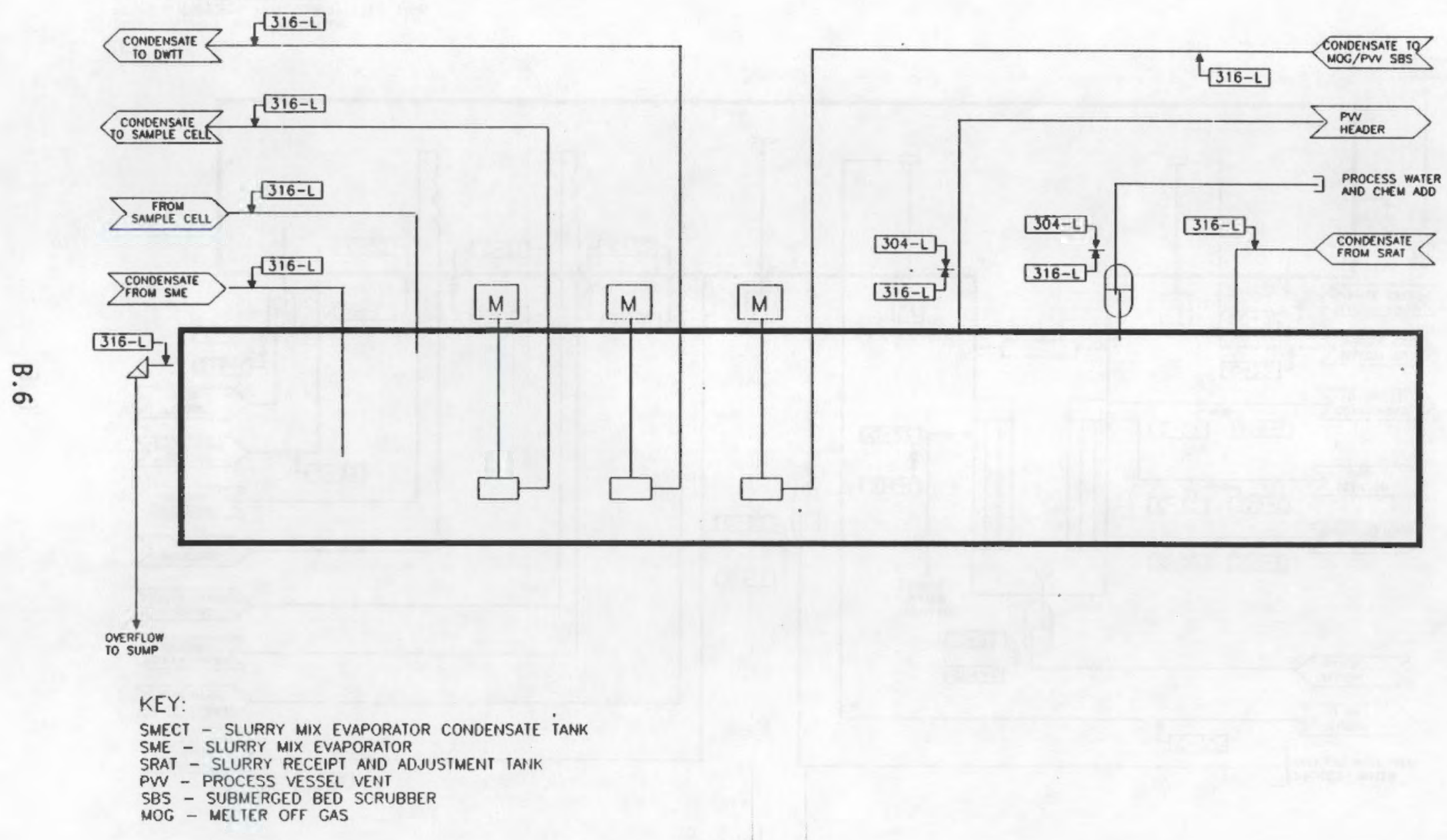

FIGURE B.5. Materials Selection Guide for the HWVP Slurry Mix Evaporator Condensate Tank 


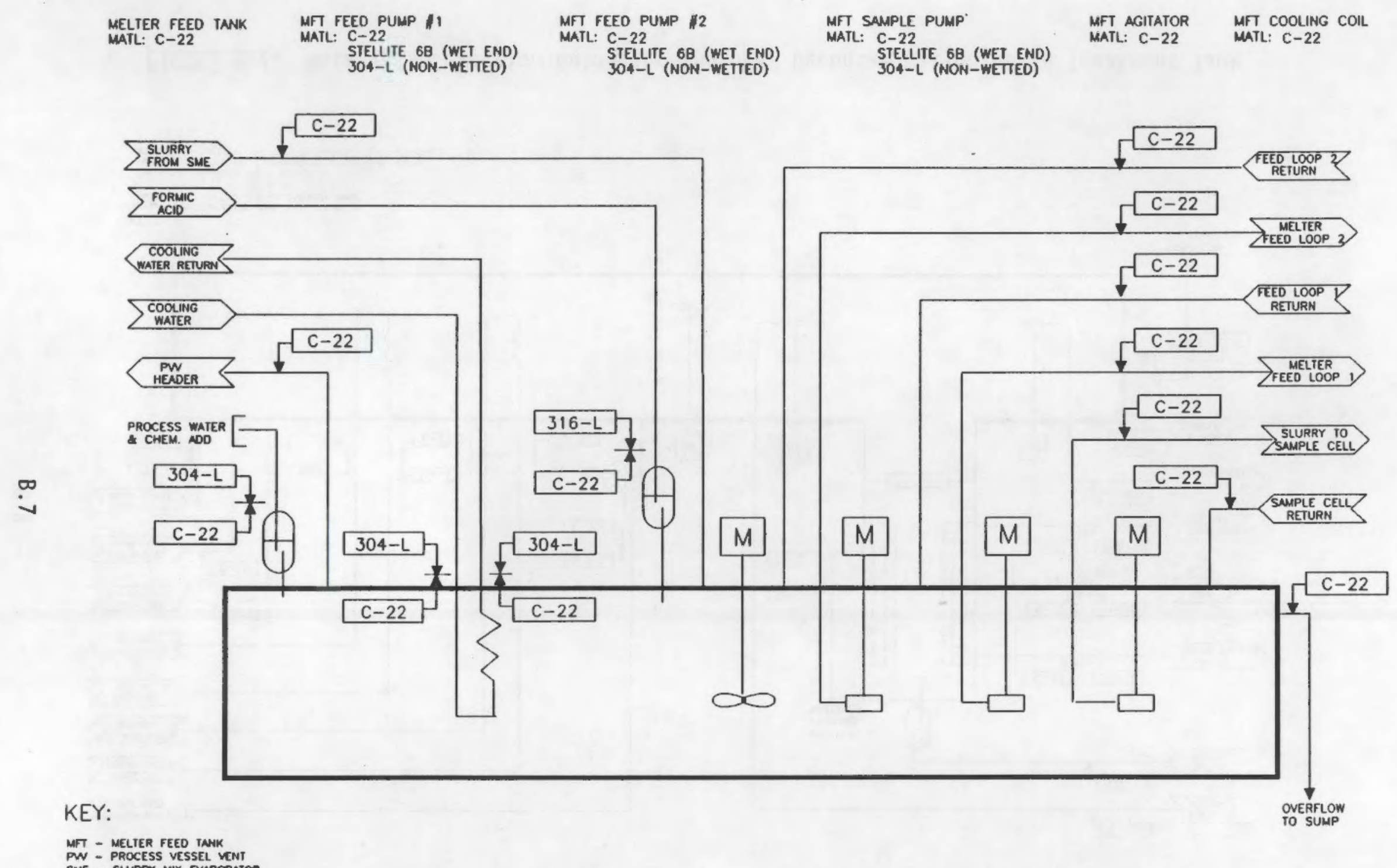

FIGURE B.6. Materials Selection Guide for the HWVP Melter Feed Tank Equipment 




FIGURE B.7. Materials Selection Guide for the HWVP Decontamination Waste Treatment Tank 


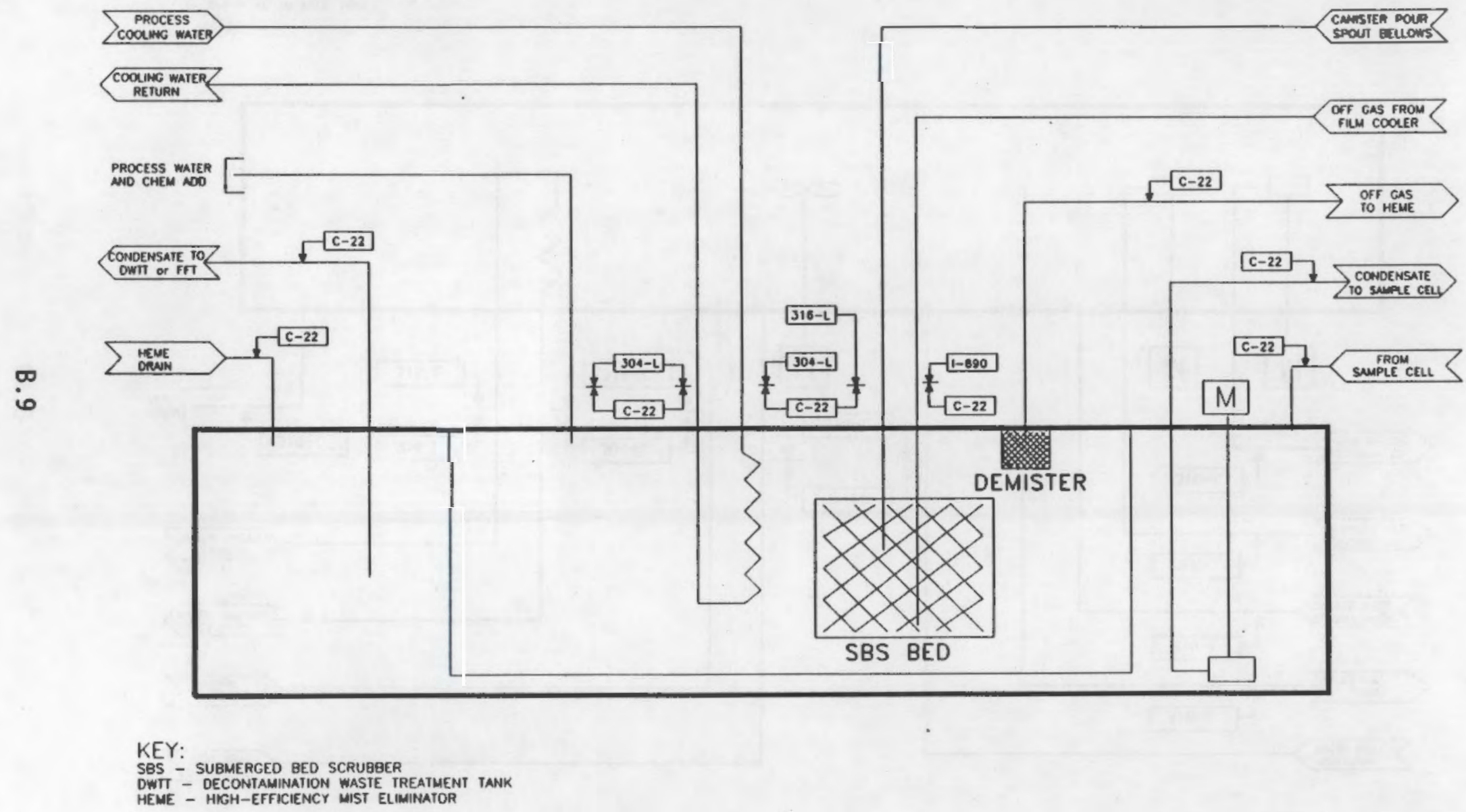

FIGURE B.8. Materials Selection Guide for the HWVP Melter Off-Gas Submerged Bed Scrubber 


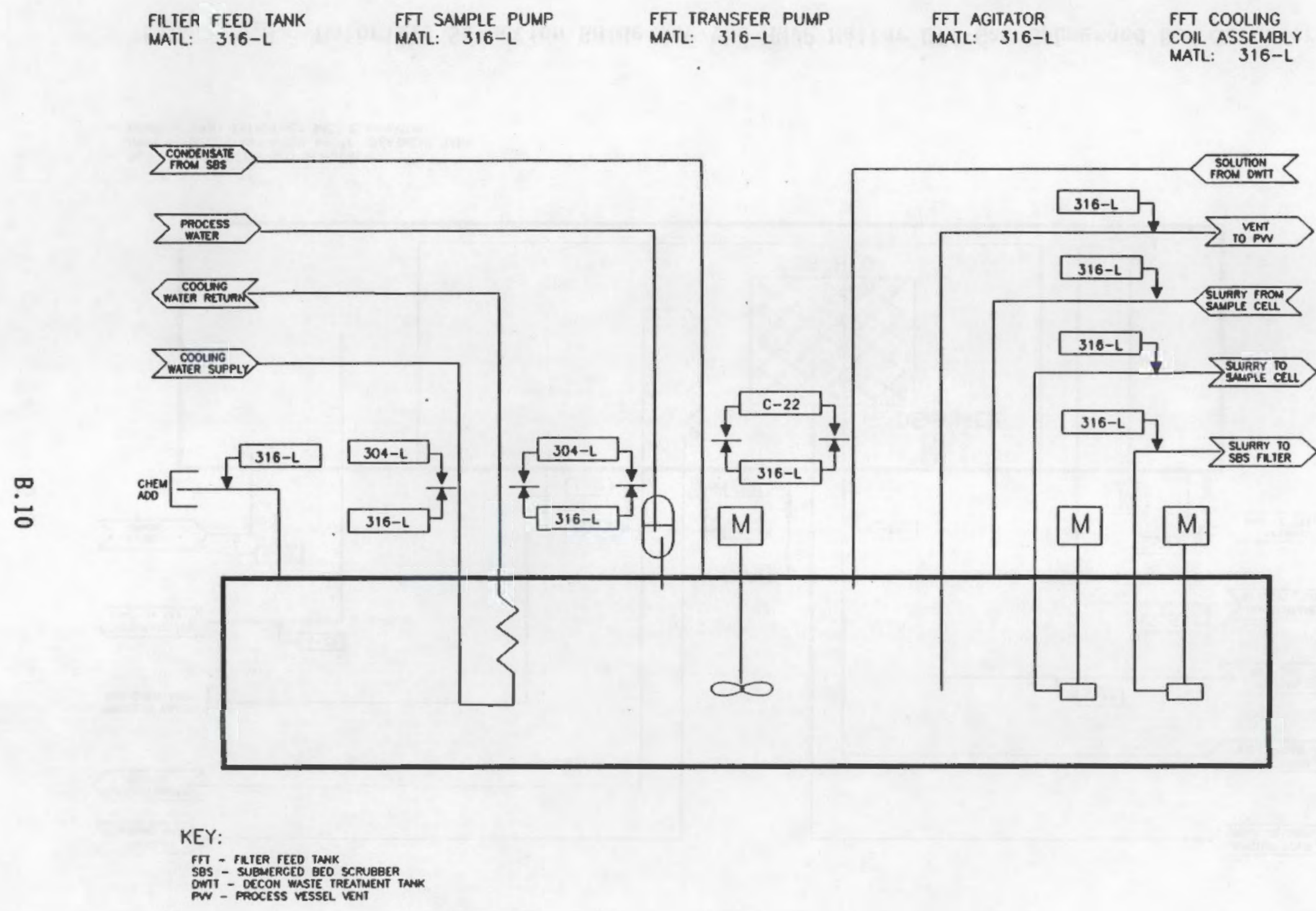

FIGURE B.9. Materials Selection Guide for the HWVP Filter Feed Tank 


\begin{tabular}{|c|c|c|c|c|c|}
\hline $\begin{array}{l}\text { RECrCLE WASTE } \\
\text { COLLECTHON TANK } \\
\text { MATL: C-22 }\end{array}$ & $\begin{array}{l}\text { RWCT } \\
\text { MAIL: }\end{array}$ & $\begin{array}{l}\text { TRANSFER PUMP } \\
\text { C-22 } \\
\text { STELLIE } 68 \text { (WET END) } \\
304-L \text { (NON-WE - ПED) }\end{array}$ & $\begin{array}{l}\text { RWCT SAMPLE PUMP } \\
\text { WAYL: SCML22 } \\
\text { STELLITE } 68 \text { (WET ENO) } \\
304-L \text { (NON-WETTEO) }\end{array}$ & $\begin{array}{l}\text { RWCT AGITATOR } \\
\text { WATL: } \\
\text { C-22 } \\
304-L \text { (NON-WETTED) }\end{array}$ & $\begin{array}{l}\text { RWCT COOLING COIL } \\
\text { MATL: } \\
\text { C-22 }\end{array}$ \\
\hline
\end{tabular}

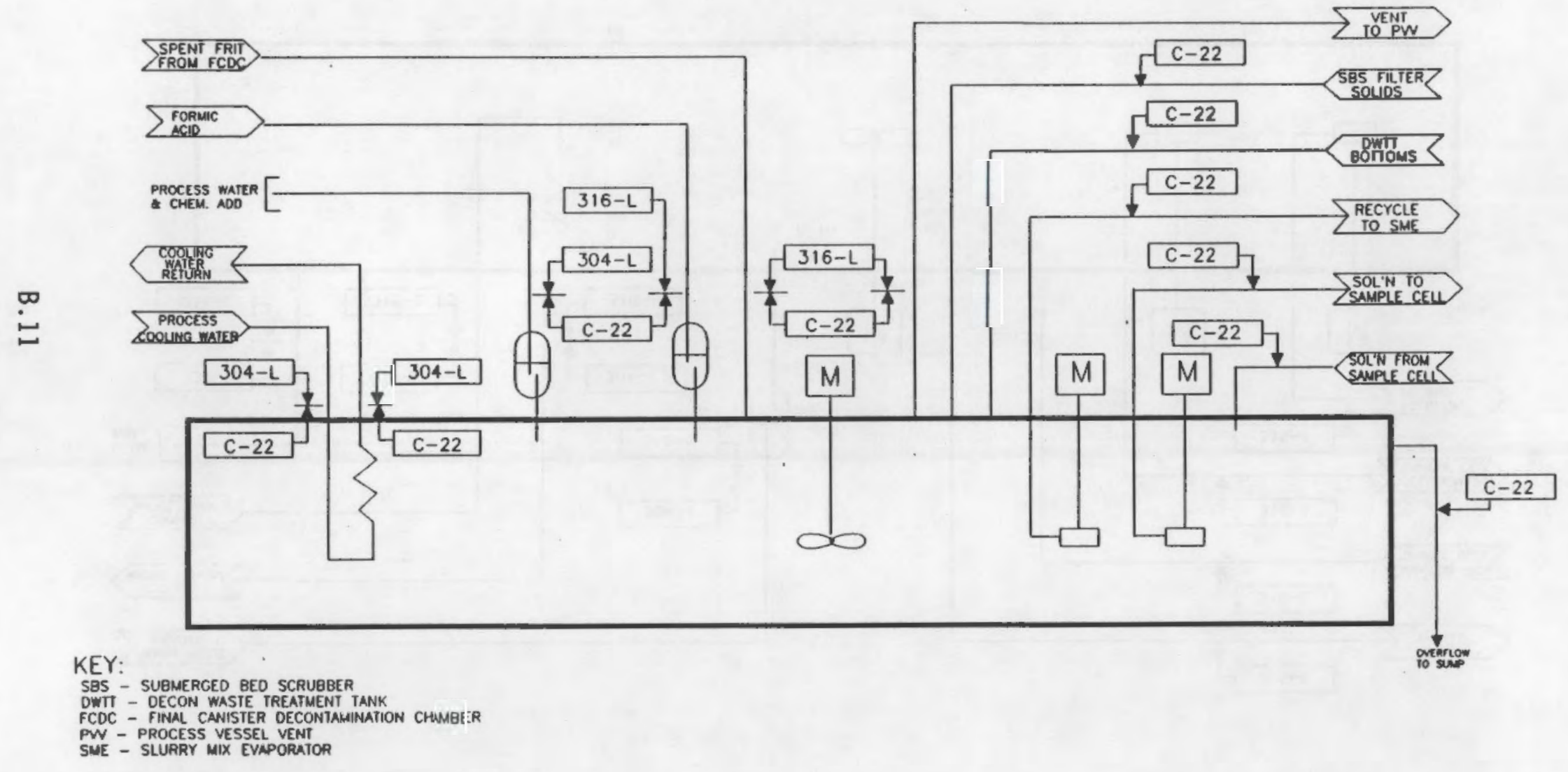

FIGURE B.10. Materials Selection Guide for the HWVP Recycle Waste Collection Tank 


WASTE ADUUSTMENT TANK WAT SAMPLE PUMP
MATL: $316-\mathrm{L}$

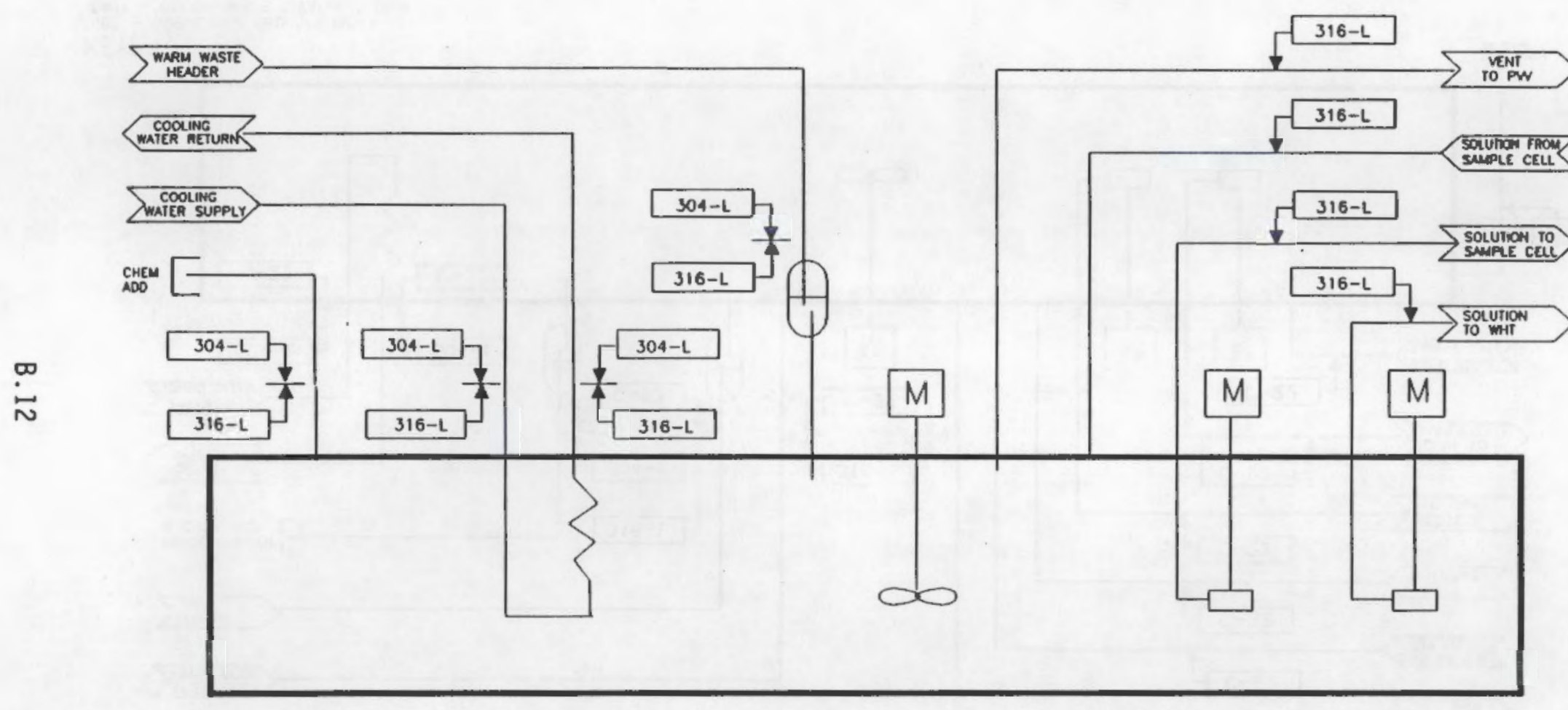

KEY:

WAT - WASTE ADJUSTMENT TANK

WHT - WASTE HOLD TANK

FIGURE B.11. Materials Selection Guide for the HWVP Waste Adjustment Tank 
PNL - 7729

UC -721

\section{DISTRIBUTION}

No. of

Copies

\section{OFFSITE}

12 DOE/Office of Scientific and Technical Information

2 DOE Office of Civilian Radioactive Haste Management Forrestal Building Washington, DC 20585

ATTN: J. W. Bartlett, RW-1

S. Brocoum, RW-22

D. B. Leclaire, $O P-30$

DOE Office of Defense Programs GTN

Washington, DC 20545

12 DOE Office of Environmental Restoration and Waste Management

\section{GTN}

Washington, OC 20545

ATTN: K. A. Chacey, EM-30

J. A. Coleman, EM-35

C. R. Cooley, EM-55

S. Cowan, EM-30

J. J. Fiore, EM-423

C. Frank, EM-50

M. Frei, EM-34

T. 5. Gutmann

J. E. Lyt]e, EM-30

T. W. McIntosh, EM-343

V. G. Trice, EM-343

H. F. Walter, EM-343

J. 0. Bunting

Division of High-Level Waste Nuclear Regulatory Commission Washington, DC 20555
No. of

Copies

J. M. Taylor Office for the Executive Director for Operations

Mail Station 17-H1

Nuclear Regulatory Commission

Washington, DC 20555

W. F. Holcomb

Environmental Protection Agency

Office of Radiation Programs (ANR-460)

401 M Street S.W.

Washington, DC 20460

P. A. Saxman

DOE Albuquerque Operations Office

P.0. Box 5400

Albuquerque, NM 87185

3 OOE Idaho Operations Office

785 DOE Place

Idaho Falls, ID 83402

ATTN: C. R. Enos

M. W. Shupe

J. E. Solecki

M. R. Jugan

DOE Oak Ridge Operations Office

P.0. Box E

Oak Ridge, TN 37830

F. T. Fong

DOE San Francisco Operations

1333 Broadway

Oakland, CA 94612

H. Brandt

DOE Savannah River Operations office

P.O. Box A

Aiken, SC 29801 
PNL - 7729

UC -721

No. of

Copies

W. S. Ketola

DOE West Valley Project

P.0. Box 191

West Valley, NY 14171

C. P. Gertz

DOE Yucca Mountain Project

Phase 2

Suite 200

101 Convention Center Drive

Las Vegas, NV 89109

3 Oak Ridge National Laboratory

P.0. Box Y

Oak Ridge, TN 37830

ATTN: S. A. Meachum

L. J. Mezga

T. H. Row

3 Sandia Laboratories

P.0. Box 5800

Albuquerque, NM 87185

ATTN: D. Knecht

R. W. Lynch, Dept. 6300

Technical Library

West inghouse Idaho Nuclear

Co., Inc.

P.0. Box 4000

Idaho Falls, I0 83401

4 Westinghouse Savannah River Co.

Savannah River Site

Aiken, SC 29801

ATTN: D. F. Bickford

J. A. Gentilucci

J. R. Knight, $773 \mathrm{~A}$

C. T. Randa I1, 7042
No. of

Copies

3 West Valley Nuclear Services Co.

P.0. Box 191

West Valley, NY 14171

ATTN: S. M. Barnes

R. R. Borisch

R. Palmer

S. G. Harbison

New York State Energy Research

\& Development Authority

P.0. Box 191

West Valley, NY 14171

I. L. White

New York State Energy Research

\& Development Authority

Empire State Plaza

Albany, NY 12223

\section{ONSITE}

4 DOE Richland Operations Office

R. W. Brown

S. T. Burnum

P. E. Lamont

E. C. Norman

10 Westinghouse Hanford Company

J. N. Appel

0 . L. Kruger

W. C. Miller

K. R. Shah

P. S. Schaus

R. A. Smith

G. E. Stegen

L. D. Swenson

E. T. Weber

D. D. Wodrich 
No of

Copies

\section{Pacific Northwest Laboratory}

C. R. Allen

H. C. Burkholder

J. H. Creer

M. R. Elmore (10)

J. R. Gaskell

G. A. Jensen (10)

G. L. Ketner

W. L. Kuhn

D. E. Larson

J. L. McElroy

J. M. Perez, Jr.

M. E. Peterson

H. A. Ross

P. A. Scott

J. M. Seay

G. J. Sevigny

R. E. Thornhi11

Publishing Coordination

Technical Report Files (5) 
$\checkmark$ 